\title{
The global bio-events at the Cenomanian-Turonian transition in the reduced Bahloul Formation of Bou Ghanem (central Tunisia)
}

\author{
Francis Robaszynski ${ }^{\mathrm{a}, *}$, Mohamed Faouzi Zagrarni ${ }^{\mathrm{b}}$, Michèle Caron ${ }^{\mathrm{c}}$, Francis Amédro ${ }^{\mathrm{d}}$ \\ ${ }^{a}$ Faculté Polytechnique, 9 rue de Houdain, 7000 Mons, Belgium \\ ${ }^{\mathrm{b}}$ Faculté des Sciences de Bizerte, 7021 Zarzouna, Tunisia \\ ' Institut de géologie de l'Université, boulevard de Pérolles, 1700 Fribourg, Switzerland \\ d 26, rue de Nottingham, 62100 Calais, France and Université de Bourgogne, UMR 5561, CNRS Biogéosciences, 6 boulevard Gabriel, 21000 Dijon, France
}

\begin{abstract}
In central Tunisia, the thickness of the Bahloul Formation varies generally between 20 to $40 \mathrm{~m}$ such as for example, respectively, at wadi Smara near Kalaat Senan and at wadi Bahloul near Maktar. The thickness is also of several tens metres at Koudiat el Azreg near Jerissa and at Tajerouine. In these sites where the thickness of the Bahloul Formation is dilated, in addition to five geochemical events $\left(\delta^{13} \mathrm{C}\right)$, nine bioevents were defined near the Cenomanian-Turonian transition, successively in ascending order: 1 . LO Rotalipora cushmani, 2. Heterohelix bio-event, 3. FO Pseudaspidoceras pseudonodosoides, 4. LO P. pseudonodosoides, 5. LO Thalmanninella multiloculata, 6. "filaments" bio-event, Cenomanian-Turonian transition, 7. FO Watinoceras sp., 8. FO Pseudaspidoceras flexuosum, 9. FO Helvetoglobotruncana helvetica. Even though the Bahloul Formation in the Bou Ghanem site is only $7.7 \mathrm{~m}$ thick (from which only $2.4 \mathrm{~m}$ of laminated black limestones), all nine marker bio-events were recorded, almost in the same order except some small differences. A good number of these bio-events are global as they are also present at Pueblo (Colorado, USA), the stratotype for the base of the Turonian stage. Consequently, at a global scale, it is possible to place the Cenomanian-Turonian boundary with one or several of these bio-events, with a good level of confidence.
\end{abstract}

\section{Introduction}

For the last two decades, the Bahloul Formation has been the subject of numerous contributions as it contains the CenomanianTuronian boundary and shows a high organic carbon accumulation representing the oceanic anoxic event OAE 2 . It consists of a rock bar of several metres to several tens of metres thick, well developed in a large part of Northern and central Tunisia. It rests on the marly Fahdene Formation and is covered by the Annaba Member of the Kef Formation. The type locality of the Bahloul Formation has been designated by Burollet et al. (1954) and Burollet (1956). There, the Formation consists of black laminated limestones alternating with dark grey calcareous marls. The Total Organic Carbon content as the hydrogen and oxygen indexes (Rock-Eval) of 22 sites were previously given by Layeb and Belayouni (1992). Descriptions and characteristics of the type Bahloul Formation have been published by Robaszynski in Burollet and Robaszynski (1992), Maamouri et al.

\footnotetext{
* Corresponding author.

E-mail address: francis.robaszynski@umons.ac.be (F. Robaszynski).
}

(1994), Ben Haj Ali et al. (1994), Caron et al. (1999, 2006) and Amédro et al. (2005). In the Kalaat Senan area, we studied three sites for their lithology, microfacies, macro- and microfossil content and geochemistry $\left(\delta^{13} \mathrm{C}\right)$ : SM section in the wadi Smara (Robaszynski et al., 1990, 1993, 1994; Robaszynski, 2005), ZR section at the Koudiat el Azreg and TJ section in the Tajerouine area (Accarie et al., 1996, 2000; Amédro et al., 2005), cf. Fig. 1.

In all these sections, the general lithology of the Bahloul Formation consists of two units: at the base, a succession of grey and massive calcispheric limestones, 3 to $6.5 \mathrm{~m}$ thick, with black laminations at the bottom, was named "pre-Bahloul" by Accarie et al. (2000); above lies the Bahloul sensu stricto composed of a succession of black limestones, generally laminated, of grey limestones sometimes nodulous or hummocky, of marly limestones and of bioturbated levels with sometimes perforated surfaces, the thickness of this second unit varying between 2 and $37 \mathrm{~m}$ (Table 1 ).

The detailed study of macrofossils and microfacies and, in addition, of the position of the major $\delta^{13} \mathrm{C}$ excursion peaks which span the Cenomanian-Turonian boundary support the succession of geochemical- and bio-events which is as follows in descending order (FO: first occurrence, LO: last occurrence): 


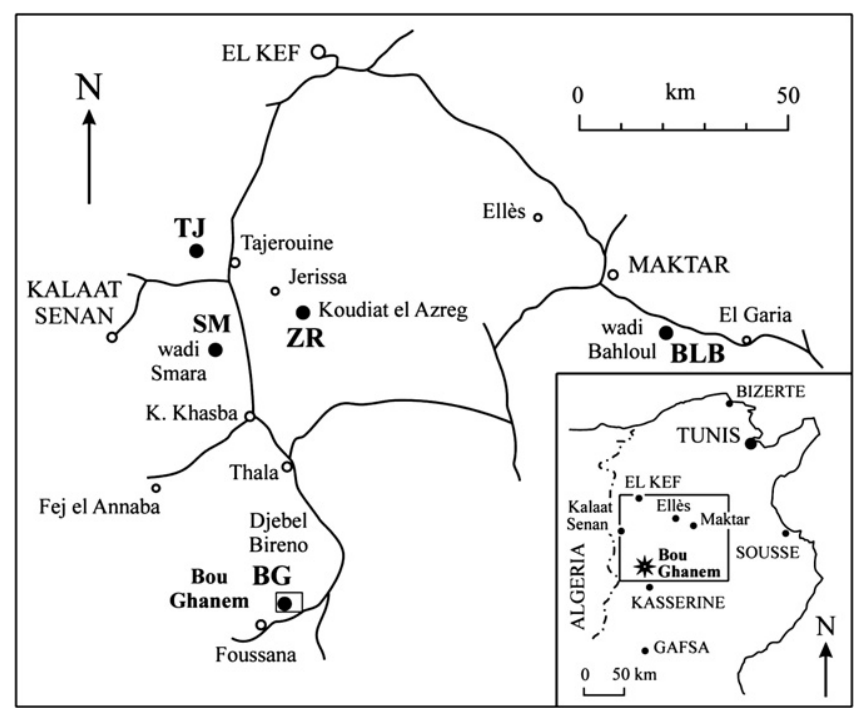

Fig. 1. Location of the Bou Ghanem site (BG) and of four other sections discussed in central Tunisia (closed circles: BLB: wadi Bahloul, ZR: Koudiat el Azreg, SM: wadi Smara, TJ: Tajerouine); open circles: cities and villages.

(FO Mammites nodosoides)

9. FO Helvetoglobotruncana helvetica

$\delta^{13} \mathrm{C}$ peak IV

8. FO Pseudaspidoceras flexuosum

7. FO Watinoceras $s p$.

CENOMANIAN-TURONIAN BOUNDARY

6. "filaments" bio-event

5. LO Thalmanninella multiloculata

(= "Anaticinella" auct.)

4. LO Pseudaspidoceras pseudonodosoides

$\delta^{13} \mathrm{C}$ peak III

$\delta^{13} \mathrm{C}$ peak II

3. FO or development of Pseudaspaspidoceras pseudonodosoides

2. Heterohelix bio-event

$\delta^{13} \mathrm{C}$ peak I

1. LO Rotalipora cushmani

(FO Whiteinella praehelvetica)

(FO Metoicoceras geslinianum)

This succession of events corresponds to sections in which the thickness of the Bahloul Formation is 20 to $40 \mathrm{~m}$. The Bou Ghanem section is quite different as the Bahloul Formation is $7.7 \mathrm{~m}$ thick from which $5.3 \mathrm{~m}$ are attributed to the pre-Bahloul unit and only $2.4 \mathrm{~m}$ for the laminated Bahloul facies. The goal of the present study was to know if the succession of bio-events as demonstrated above in dilated sections is truncated or complete in the reduced section of Bou Ghanem.

\section{Materials and methods}

The study started with fieldwork in outcrops along gullies just SW of Kef oum Fedra (Fig. 2) which is about $7 \mathrm{~km} \mathrm{SW}$ of Djebel

Table 1

Thicknesses of lithological units in the Bahloul Formation of 5 sites in central Tunisia

\begin{tabular}{lllll}
\hline Section & Index & $\begin{array}{l}\text { Total Bahloul } \\
\text { Fm. thickness }(\mathrm{m})\end{array}$ & $\begin{array}{l}\text { Pré-Bahloul } \\
\text { thickness }(\mathrm{m})\end{array}$ & $\begin{array}{l}\text { Bahloul s.s. } \\
\text { Thickness }(\mathrm{m})\end{array}$ \\
\hline Bahloul & BLB & 40 & 3 & 37 \\
Azreg & ZR & 36 & 4 & 32 \\
Smara & SM & 23 & 4 & 19 \\
Tajerouine & TJ & 20 & 6.5 & $>12$ \\
Bou Ghanem & BG & 7.7 & 5.3 & 2.4 \\
\hline
\end{tabular}

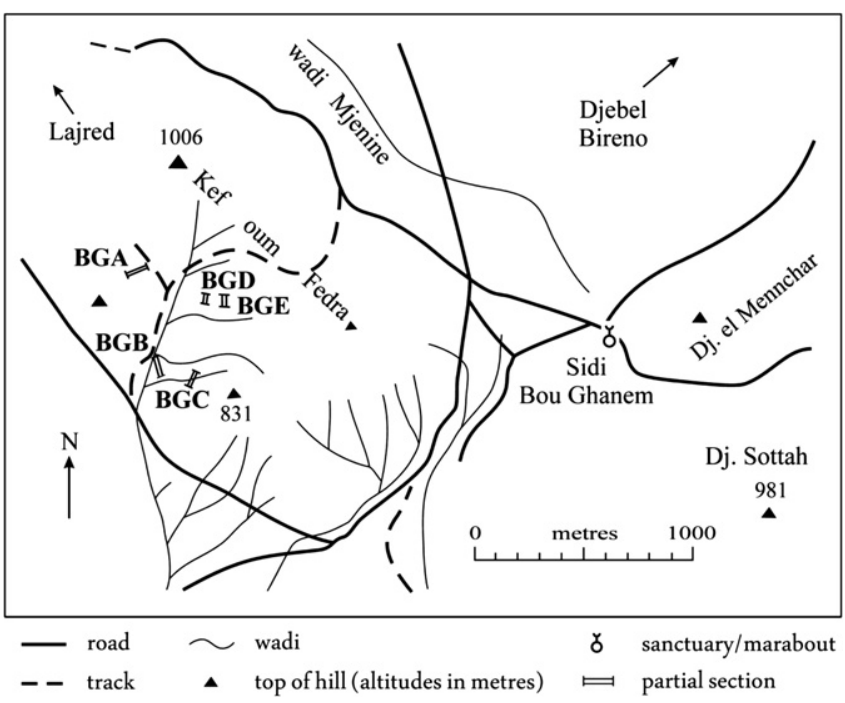

Fig. 2. Location of partial sections in the Bou Ghanem site.

Bireno and $2 \mathrm{~km}$ W of the Bou Ghanem hamlet. Five partial sections have been measured BGA to BGE and correlation between these sections were assumed de visu in the field with lithological marker levels (Figs. 3-7). A composite log is representative of the complete stratigraphical succession encompassing the Cenomanian-Turonian boundary (Fig. 8). Closely-spaced samples were taken for microfacies analysis: 5 for BGA, 18 for BGB, 9 for BGC, 4 for BGD and 2 for BGE, that is to say 38 samples spanning about $20 \mathrm{~m}$ of the composite section. All along the partial sections macrofossils were collected, especially ammonites which are not rare and are essentially located in the BGB section. Some ammonites occurring as negative imprints at the surface of beds, plaster casts were taken to avoid the breaking up of the flimsy imprints and to assure a better determination.

Most of the samples were prepared in thin sections perpendicular to the stratification.

Two sets of thin sections were prepared. The first set " 1 ère série, 1998") consists of 40 thin sections labelled as follows: BGA $1.50,2.20,2.90,2.95,8.50$; BGB $0.40,0.45 a, 0.45 b, 1.10,1.15,1.35$, $1.60,2.00,2.10,2.20,2.25,2.50,2.55,2.70,2.75,2.80,3.35,3.60$, 4.10; BGC 2.00, 2.05, 2.35, 2.65, 2.75, 5.00, 5.80, 6.65; BGD 0.20, $0.60,0.70$ (3 sections), 0.90; BGE 1.90, 3.20. The second set ("2ème série, 2004") consists of 28 thin sections labelled as follows

BGA 1.50, 2.20, 2.90, 2.95, 8.50; BGB 0.40, 0.45b, 1.15, 1.60, 2.00, 2.25, 2.50, 2.55, 2.70, 2.75, 2.80, 3.10, 3.35, 4.10; BGC 5.00, 5.80, 6.65; BGD 0.20, 0.60, 0.70, 0.90; BGE 1.90, 3.00. All thin sections are deposited at the Institut de Géologie de Fribourg but will return in Tunisia in the collections of M.F. Zagrarni who are actually at the Faculté des Sciences de Bizerte.

Some photographs were shot in the field to show general views of sections BGA, BGB and BGC (Fig. 9 A, B and C) and also close views of the BGB laminated limestones wherein lies the CenomanianTuronian boundary (Fig. 10).

\section{Description of the Bou Ghanem partial sections}

\subsection{The $B G A, B G D$ and $B G E$ sections (Figs. 3-5 and $9 A$ )}

In the $8.70 \mathrm{~m}$, six lithological units (LU) are distinguished (LU 1 to 6 ).

LU 1: $2.40 \mathrm{~m}$ from BGA 0 to $2.40 \mathrm{~m}$. It is an alternation of grey limestones ( 0.2 to $0.3 \mathrm{~m}$ thick) and grey calcareous marls ( 0.1 to 


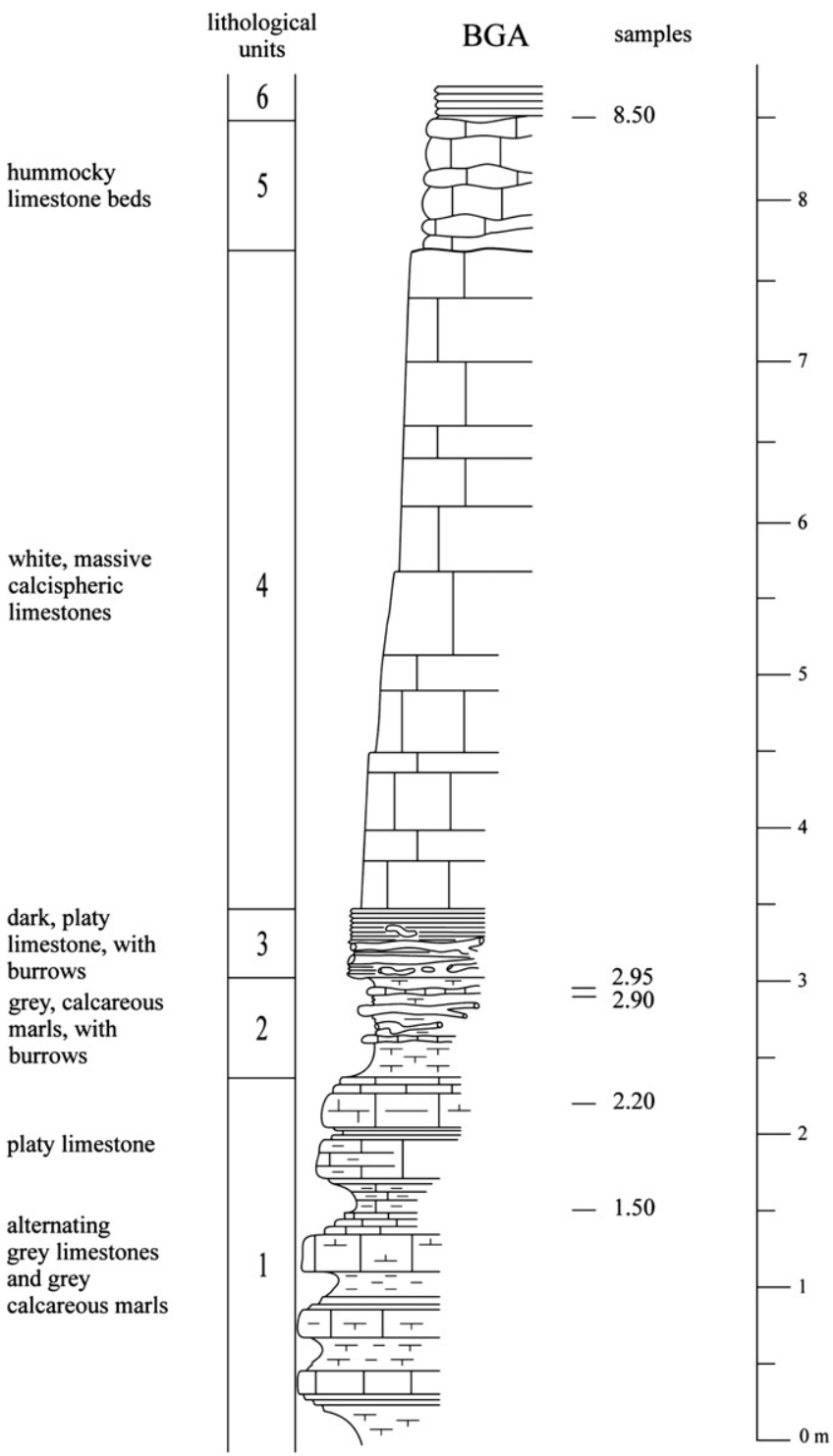

Fig. 3. Lithological succession of the partial section BGA. Description of each lithological unit is given on the left.

$0.3 \mathrm{~m}$ ). In thin sections, calcareous marls are packstones to wackestones with numerous calcispheres (calcareous dinoflagellates), pithonellids (calcareous Dasycladal green algae cysts or calcareous dinocysts), rare globular planktonic foraminifera and some agglutinated benthic foraminifera as Hemicyclammina sp. Limestones appear as wackestones with calcispheres and numerous planktonic foraminifera (Heterohelix and Whiteinella spp.)

\subsection{1. $L U$ 2: $0.65 \mathrm{~m}$ from BGA 2.40 to $3.05 \mathrm{~m}$}

It is a grey calcareous marl crossed by large burrows parallel to the stratification, 1 to $4 \mathrm{~cm}$ in diameter, with a lot of echinoids tests and spine fragments. In thin sections, within a wackestone to packstone texture, calcispheres, fragments of serpulids, echinoids, ostracods, benthic foraminifera (agglutinated Hemicyclammina, calcareous buliminids) and planktonic foraminifera (Whiteinella, Hedbergella, Globigerinelloides) are well represented.

The units LU 1 and $L U 2$ represent the topmost part of the Fahdene Formation.

\subsection{2. $L U$ 3: $0.45 \mathrm{~m}$ from BGA 3.05 to $3.50 \mathrm{~m}$}

This unit represents the base of the Bahloul Formation as it contains the first black laminated structures. It is a dark grey and platy limestone, roughly laminated, with distinct burrows of the same type as in LU 2, sometimes dichotomic. Thin sections show lines of calcispheres and lines of planktonic foraminifera with globular chambers (Hedbergella and Whiteinella spp.) alternating with lines of saccocomids and dark organic matter (Fig. 11C and D). Of note is the presence of a section of Thalmanninella multiloculata.

\subsection{3. $L U$ 4: $4.20 \mathrm{~m}$ from $B G A 3.50$ to $7.70 \mathrm{~m}$}

This unit is a bar appearing as a rock step in the landscape. It consists of massive beds of white calcispheric limestones, very hard, reddish-brown when the bed surfaces are weathered. The uppermost level (BGA $8.50 \mathrm{~m}$ ) is a hard calcispheric packstone with tiny bioclasts and small oysters. In thin section, calcispheres are abundant and arranged in a packstone to wackestone texture. Presence of some saccocomids, inoceramid, echinoid and bivalve fragments, rare planktonic foraminifera (Whiteinella, Rotalipora), rare benthic foraminifera. The last occurrence of Rotalipora cushmani, an important planktonic foraminiferal marker, at BGE $1.90 \mathrm{~m}$ (corresponding approximately to BGA $4.80 \mathrm{~m}$ ) constitutes bioevent 1.

\subsection{4. $L U$ 5: $0.80 \mathrm{~m}$ from $B G A 7.70 \mathrm{~m}$ to $8.50 \mathrm{~m}$}

Limestone beds which upper surface have a mammilated aspect. As LU 3 to 5 are light-coloured limestones, they are considered as belonging to the pre-Bahloul succession.

\subsection{5. $L U$ 6: $0.20 \mathrm{~m}$ visible at top of section, above BGA $8.50 \mathrm{~m}$}

Dark grey laminated limestones forming the base of the Bahloul S.s. succession.

\section{lithological units}

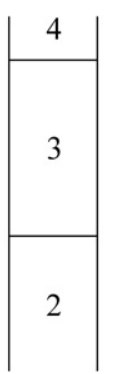

BGD

samples

\begin{abstract}
calcispheric limestone
platy limestone, with burrows

calcareous marls, with burrows
\end{abstract}
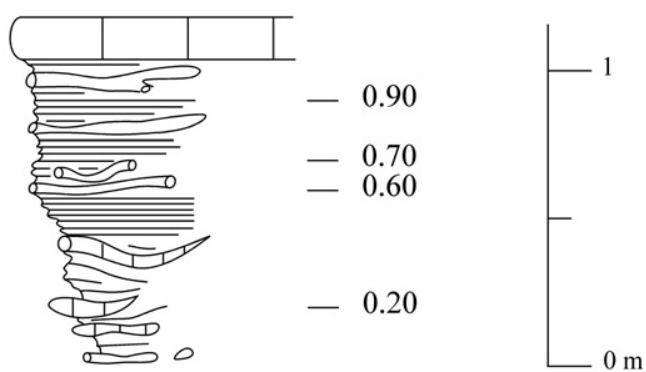

Fig. 4. Lithological succession of the partial section BGD. 


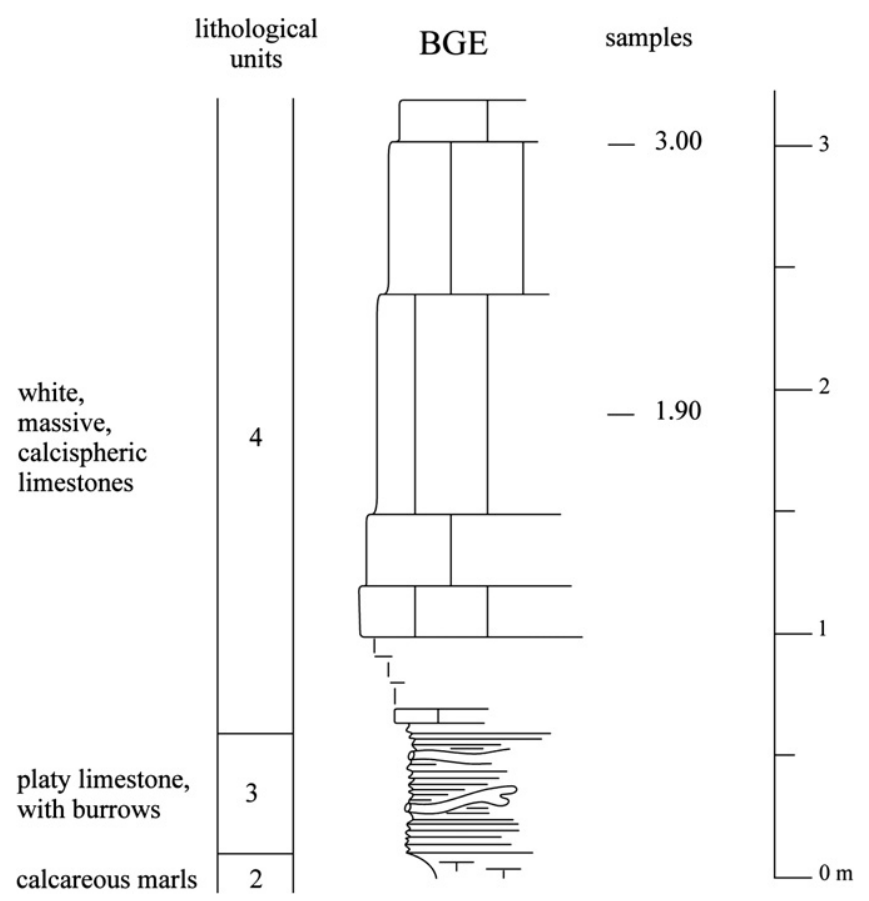

Fig. 5. Lithological succession of the partial section BGE.

\subsection{The BGB section (Figs. 6, $9 B$ and 10)}

Seven lithological units are distinguished in the $4.10 \mathrm{~m}$ measured section.

\subsection{1. $L U$ 4: $0.40 \mathrm{~m}$ visible at the base of the section; from} BGB 0 to 0.40

White calcispheric limestones of which, the top surface is mamillated and encrusted with small oysters. A piece of the ammonite Calycoceras sp. was found at the top. Thin sections give the same aspect as in BGA: packstone with calcispheres, saccocomids, rare benthic foraminifera (Hemicyclammina) and more planktic foraminifera (Hedbergella and Whiteinella spp).

\subsection{2. $L U$ 5: $0.70 \mathrm{~m}$ from $B G B 0.40$ to $1.10 \mathrm{~m}$}

Grey calcispheric limestones formed of lenticular-shaped and mamillated beds of 0.1 to $0.2 \mathrm{~m}$ thick appearing as hummocks. The bottom of undulations are covered with thin sheets of marly and bioclastic limestone. As this unit does not present laminations it is still regarded to belong to the pre-Bahloul. The top of the unit is slightly burrowed and encrusted with small oysters. In the upper $0.2 \mathrm{~m}$ of these limestones several ammonites were found: an indeterminate vascoceratid and some acanthoceratids belonging to the genera Nigericeras and (?)Pseudaspidoceras. The thin sections in the limestone hummocks show packstones with numerous calcispheres, some saccocomids and rare planktic foraminifera with globular chambers.

\subsection{3. $L U$ 6: $0.25 \mathrm{~m}$ from $B G B 1.10$ to $1.35 \mathrm{~m}$}

Dark grey platy limestone, roughly laminated. It is regarded as the base of the Bahloul s.s. facies. Thin sections show very abundant planktic foraminifera belonging to the Heterohelix genus in a packstone and rare saccocomids in carbonate-rich cement with black organic matter. The sudden development of Heterohelix ('Heterohelix shift' of Caron et al., 2006) is bio-event 2 which marks the first organic-carbon rich laminae at the basal part of the Bahloul s.s. in central Tunisia.

\subsection{4. $L U$ 7: $0.65 \mathrm{~m}$ from $B G B 1.35$ to $2 \mathrm{~m}$}

Black limestones, finely laminated in the lower half and platy above. The top of the unit is a light-coloured bioclastic limestone, 3 to $8 \mathrm{~cm}$ thick, which penetrates by burrows of Thalassinoides type into the underlying platy dark limestone; a good fragment of the ammonite Nigericeras sp. was found at BGB 2. Thin sections show a succession of parallel lines of abundant Heterohelix alternating with lines of mudstone with very dark organic matter. Several laminae may contain some scattered "filaments" (juvenile thinshelled pelagic bivalves known in the Jurassic as Bositra buchii, (cf Wignall, 1994) and phosphate grains. Of note is the presence at BGB 1.60 of a section of Thalmanninella gr. multiloculata which is a retroevolutionary morphotype of the Thalmanninella group ('Anaticinella' auct.). The top of the unit contains bioclasts, saccocomids and planktic foraminifera of the Whiteinella genus (W. archaeocretacea, W. paradubia, $W$. praehelvetica).

\subsection{5. $L U$ 8: $0.70 \mathrm{~m}$ from $B G B 2$ to $2.70 \mathrm{~m}$}

Dark grey to black laminated to platy limestones with interbedded grey-coloured calcispheric limestones, undulated to lenticular. The base is dark, fine grained and laminated whereas the top is grey, platy and bioclastic. Ammonites are well represented in the unit: a vascoceratid at BGB 2.40 , but particularly Pseudaspidoceras pseudonodosoides with its FO and LO respectively at BGB 2.30 and 2.50. In thin sections, limestones of wackestone to packstone texture contain calcispheres, some saccocomids, inoceramid fragments and phosphate grains, planktic foraminifera such as Whiteinella (archaeocretacea and praehelvetica) and Th. multiloculata at BGB 2.10 and $2.50 \mathrm{~m}$. The "filaments" become abundant from BGB 2.55 .

Due to the condensation of the sedimentation in the higher part of LU 8, 5 bio-events are concentrated between the levels BGB 2.30 and $2.60 \mathrm{~m}$, successively: bio-event 3 at BGB $2.30 \mathrm{~m}$ (FO of P. pseudonodosoides), bio-event 4 at BGB $2.50 \mathrm{~m}$ (LO of $P$. pseudonodosoides), bio-event 5 at BGB $2.50 \mathrm{~m}$ (LO of Th. multiloculata), and bio-event 6 at BGB $2.55 \mathrm{~m}$ (first manifestation of the "filaments" bio-event).

In the BGC section, at the level BGC $0.40 \mathrm{~m}$ which corresponds to the level BGB $2.60 \mathrm{~m}$ was collected the ammonite Watinoceras sp. which first occurrence is bio-event 7 , marker of the base of the Turonian stage.

\subsection{6. $L U$ 9: $0.70 \mathrm{~m}$ from $B G B 2.70$ to $3.40 \mathrm{~m}$}

Dark grey to black rhythms of laminated to platy and then to compact limestones showing small burrows at their tops. Three rhythms are clearly exposed and, above, are grey platy limestones. In thin sections, the texture is wackestone to packstone, becoming mudstone in the upper part of the unit. There are few calcispheres and saccocomids whereas planktic foraminifera are abundant, with Heterohelix, big Whiteinella (archaeocretacea, paradubia, praehelvetica at BGB $3.10 \mathrm{~m}$ ), Guembelitria at BGB $2.80 \mathrm{~m}$ and then higher up, these same planktic foraminifera are scattered in a carbonate-rich black matrix with organic matter and with some brown phosphatic grains. From BGB 2.70 m, "filaments" become very abundant.

\subsection{7. $L U$ 10: $0.70 \mathrm{~m}$ from $B G B 3.40$ to $4.10 \mathrm{~m}$}

Grey massive limestone with small burrows at the top. On the bed surface at BGB $4.10 \mathrm{~m}$ several ammonites were collected: Watinoceras sp., Fagesia sp. and ?Thomasites. Thin section shows a mudstone to wackestone texture with big Whiteinella (archaeocretacea and praehelvetica at BGB $4.10 \mathrm{~m}$ ), Heterohelix, Guembelitria, some double-keeled forms, some calcispheres and frequent "filaments". The carbonate-rich matrix contains numerous pelletoids of organic matter. 
grey, massive limestones

dark grey to black, laminated to platy and massive limestones

dark, laminated to platy limestones and

grey, undulated to lenticular limestones bioclastic limestone platy limestone

black laminated limestone

platy limestone

grey, calcispheric, hummocky limestones

white, calcispheric, massive limestone lithological units

BGB

samples

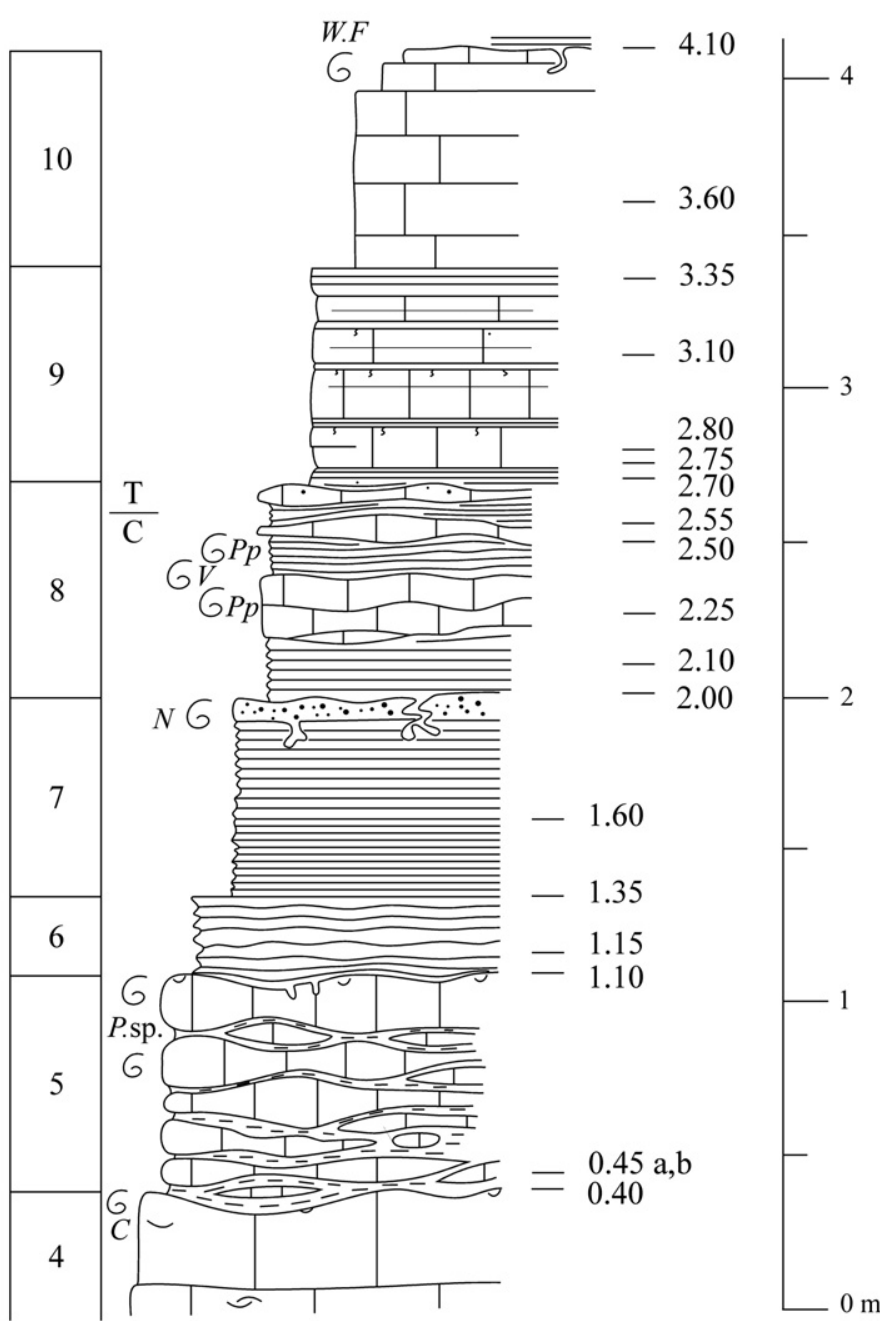

Fig. 6. Lithological succession of the partial section BGB. Ammonites, C: Calycoceras sp., F: Fagesia sp., N: Nigericeras sp., Pp: Pseudaspidoceras pseudonodosoides, Psp: Pseudaspidoceras sp., V: vascoceratid, W: Watinoceras sp., C/T: Cenomanian/Turonian boundary.

As this unit is a massive limestone, not laminated, it is considered to start the Annaba Member of the Kef Formation. Consequently, the Bahloul s.s. is regarded to end at BGB $3.40 \mathrm{~m}$.

\subsection{The BGC section (Figs. 7 and $9 C$ )}

This section is situated about $150 \mathrm{~m}$ east of the BGB section. The bed BGB $4.10 \mathrm{~m}$ was visually followed and corresponds to BGC 2 .

\subsection{1. $L U 8$ and 9: $1.30 \mathrm{~m}$ from BGC 0 to $1.30 \mathrm{~m}$}

These two lithological units were described in the BGB section. They offer a rich ammonite content with $P$. pseudonodosoides (BGC $0.10 \mathrm{~m}$ ), Watinoceras sp. (at BGC $0.40 \mathrm{~m}$ correlated to BGB $2.60 \mathrm{~m}$ ) its first occurrence marking the basal Turonian, Fagesia sp. (BGC 0.70 and $1.60 \mathrm{~m}$ ).

\subsection{2. $L U$ 10: $0.70 \mathrm{~m}$ from $B G C 1.30$ to $2 \mathrm{~m}$}

Grey massive limestone, not laminated, forming the base of the Annaba Member. It contains several ammonites as Watinoceras sp. and Pseudaspidoceras flexuosum at BGC 2 (corresponding to BGB $4.10 \mathrm{~m}$ ), the first occurrence of the latter being bio-event 8 .

\subsection{3. $L U$ 11: $0.80 \mathrm{~m}$ from $B G C 2$ to $2.80 \mathrm{~m}$}

Dark platy limestones, more grey and compact towards the base and with more marls in the upper part of the unit. Thin sections reveal wackestone-packstone to mudstone textures with various planktic foraminifera as big Whiteinella, Hedbergella, Clavihedbergella, Guembelitria, Dicarinella hagni (BGC 2) and Helvetoglobotruncana helvetica (BGC $2.35 \mathrm{~m}$ ). The matrix contain some calcispheres, phosphatic grains and organic matter. "Filaments" become rare above BGC $2.65 \mathrm{~m}$.

\subsection{4. $L U$ 12: $7.20 \mathrm{~m}$ from $B G C 2.80$ to $10 \mathrm{~m}$}

Grey-bluish calcareous marls alternating with grey marly limestones. This unit is very characteristic of the lower part of the Annaba Member of the Kef Formation.

\section{Illustration of the microfacies from the different lithological units}

The microfacies of the 12 lithological units are presented in the Figs. 11 and 12, and Fig. 13 illustrates the main planktic foraminifera, some of them being biostratigraphic markers. 
lithological

units

BGC

samples

marly

limestones

and

grey-bluish

calcareous

marls

dark, platy

limestones

grey massive

limestones

grey to black, laminated

to platy limestones

$\frac{\mathrm{T}}{\mathrm{C}}$

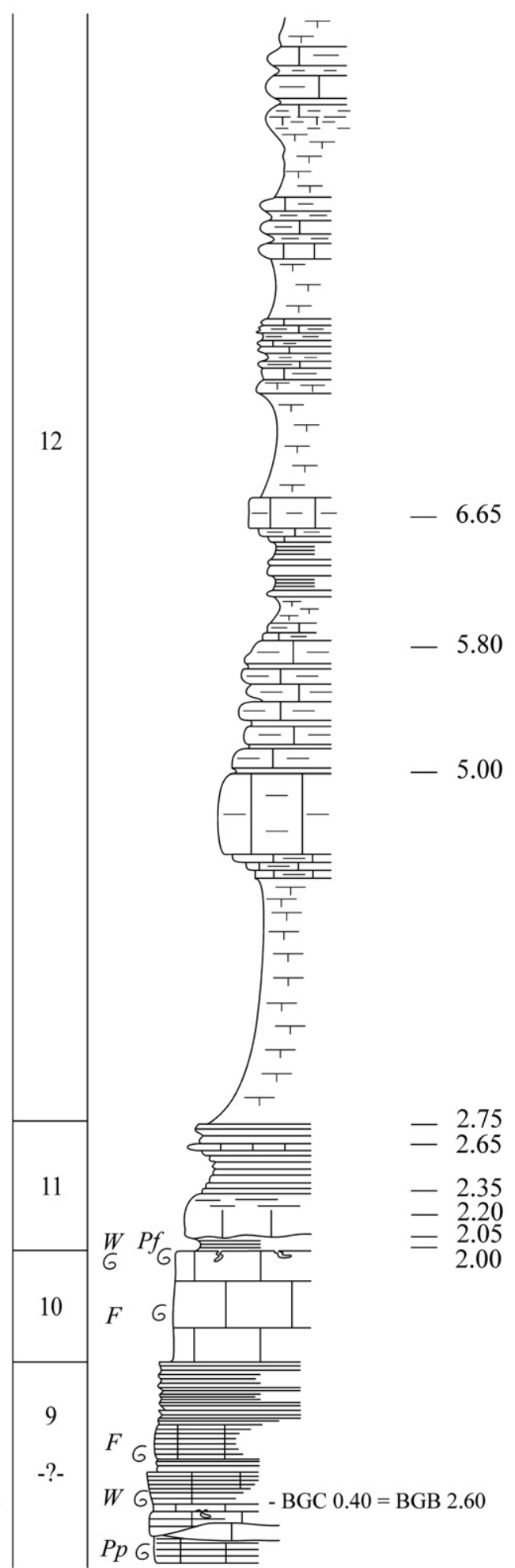

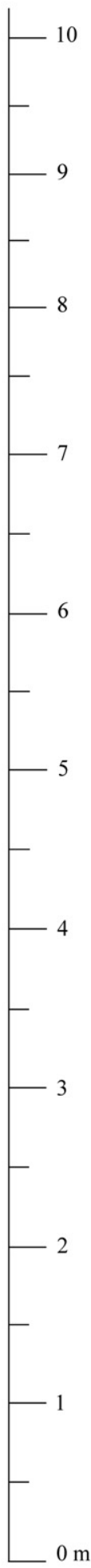

Fig. 7. Lithological succession of the partial section BGC. Ammonites, F: Fagesia sp., Pf: Pseudaspidoceras flexuosum, Pp: Pseudaspidoceras pseudonodosoides, W: Watinoceras sp.

\subsection{Comments}

As elsewhere in central Tunisia, the Bahloul Formation is characterized by laminated or platy limestone facies, rich in black organic matter. In the Bou Ghanem site, it is the case for LU 3 (first laminae: Fig. 11C), and LU 5 to 9 (laminated as in Fig. 11G). Another general character is the presence just above the base of the Bahloul Formation of a white to grey massive calcispheric limestone bed, 


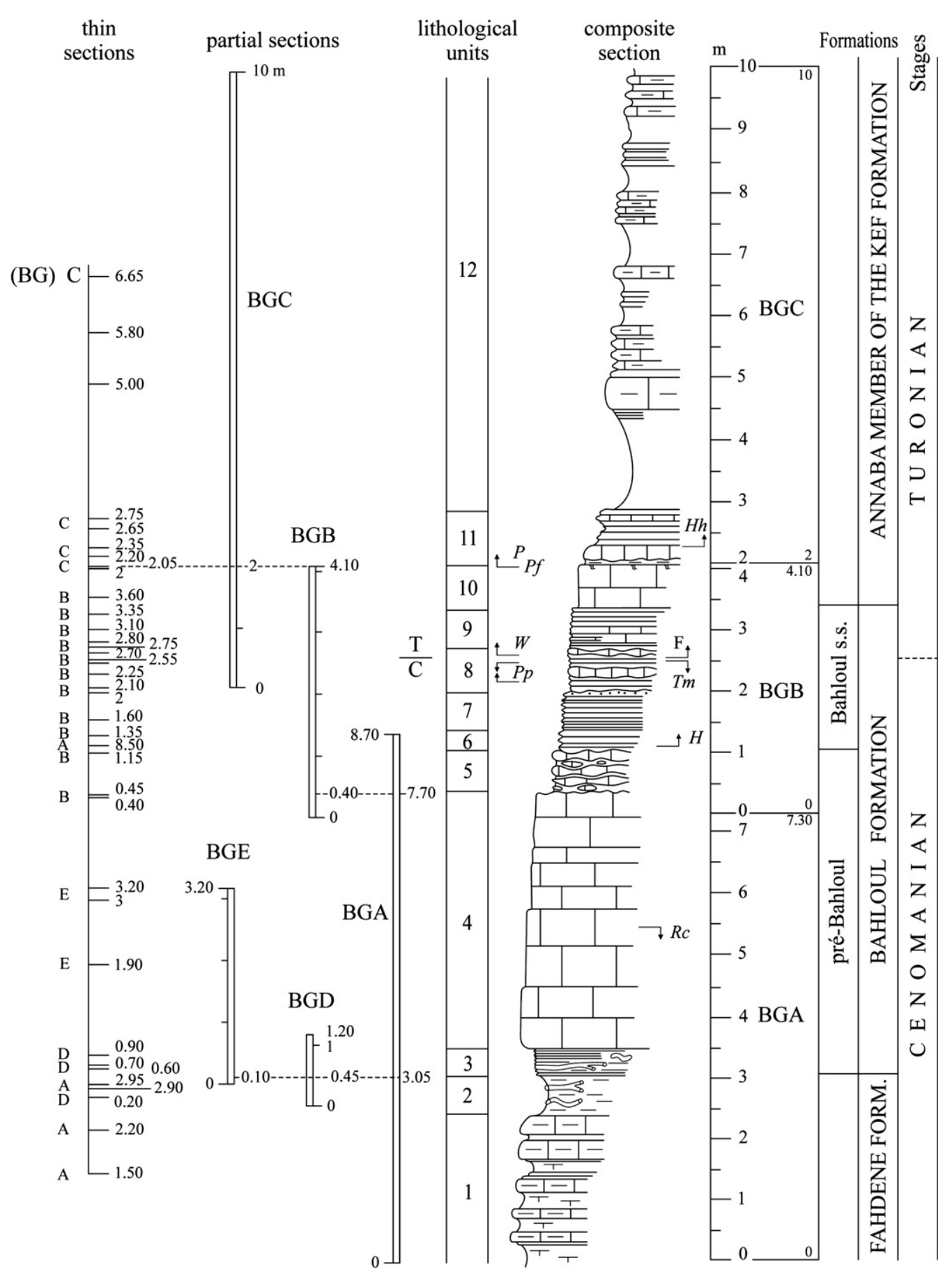

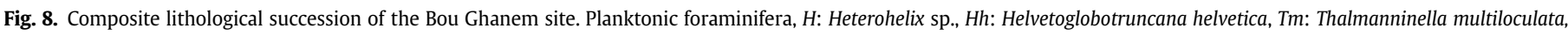

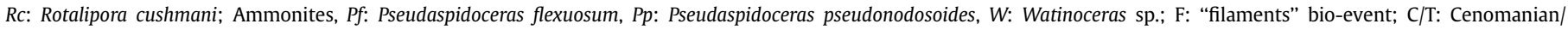
Turonian boundary.

not laminated (LU 4 of the pre-Bahloul unit, Fig. 11D), the top of which is marked by a level of grey limestone beds, also not laminated, with lenticular hummocks, which probably could be linked to distal tempestites (LU 5, Fig. 11E, with abundant bioclasts and calcispheres).

What is very peculiar to the Bou Ghanem site is the large thickness of the massive calcispheric limestone bed attaining about $5 \mathrm{~m}$ whereas elsewhere in the northern part of central Tunisia it is about 1 to $2 \mathrm{~m}$, and the drastic reduction in the thickness of the laminated Bahloul s.s., which is about $2.4 \mathrm{~m}$ whereas elsewhere it may attain 10 to $36 \mathrm{~m}$.

These distinctive features were also recognized at Fej el Annaba, some kilometres west of Thala. Particularly, below a black laminated Bahloul s.s. of less than $2 \mathrm{~m}$, is a calcispheric bed of about $3 \mathrm{~m}$ thick, having the same characteristics as the LU 4 of Bou Ghanem. This kind of facies generally appears south of the Kalaat Senan area, from about the Djebel Bireno region towards the South. It was considered as a (translated from French) "bar of Gattar facies, 

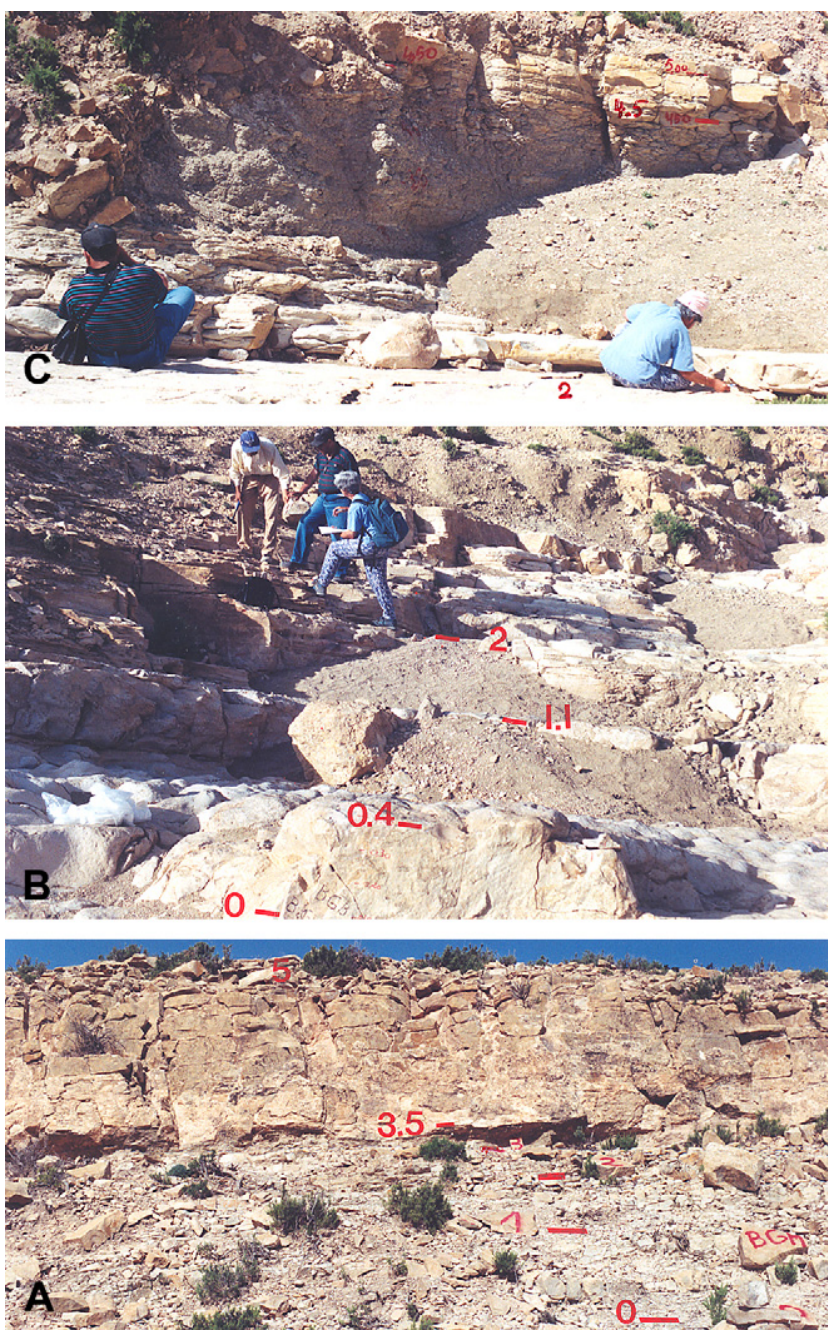

Fig. 9. A, Outcrop of part of BGA section (LU: lithological unit). 0-3: LU 1 and 2, top of the Fahdene Formation; 3-3.5: LU 3, base of the pre-Bahloul unit; 3.5-6: lower part of LU 4, calcispheric white limestone of the pre-Bahloul unit. B, Outcrop of part of BGB section. 0.40: top LU 4; 1.1: top of LU 5; 2: top of LU 7; the geologists are standing on LU 8. C, Outcrop of part of BGC section: the geologists are sitting on BGC 2, top of LU 10 first unit of the Annaba Member; 4.5: base of a limestone bed above calcareous marls of the LU 12. Photographs by F. Robaszynski.

intercalated in the Bahloul facies" by Burollet (in Burollet and Robaszynski, 1992; stop 6 and Fig. 7). Nethertheless the typical Gattar facies, named in the Gafsa area (Fournié, 1978), is generally dolomitic and placed above the Bahloul facies (Abdallah, 1995; Abdallah et al., 2000). As the Fej el Annaba calcipheric limestone bar is not dolomitic and is placed below the Bahloul s.s., it should not be considered as a Gattar equivalent.

The study of the microfacies of the Bou Ghanem site is also important as it gives the position of 5 bio-events which are good stratigraphic markers, or proxies for the Cenomanian-Turonian boundary. One of them is of regional value (the Heterohelix bioevent 2), the others being of a more global value as shown also by Caron et al. (2006): LO of R. cushmani (bio-event 1), LO of Th. multiloculata (bio-event 5), "filaments" accumulation (bio-event 6) and entry of $H$. helvetica (bio-event 9).

\section{Biostratigraphy and bio-events}

All data about lithology, samples, ammonite and planktic foraminiferal distributions, microfacies (bio- and mineral elements)
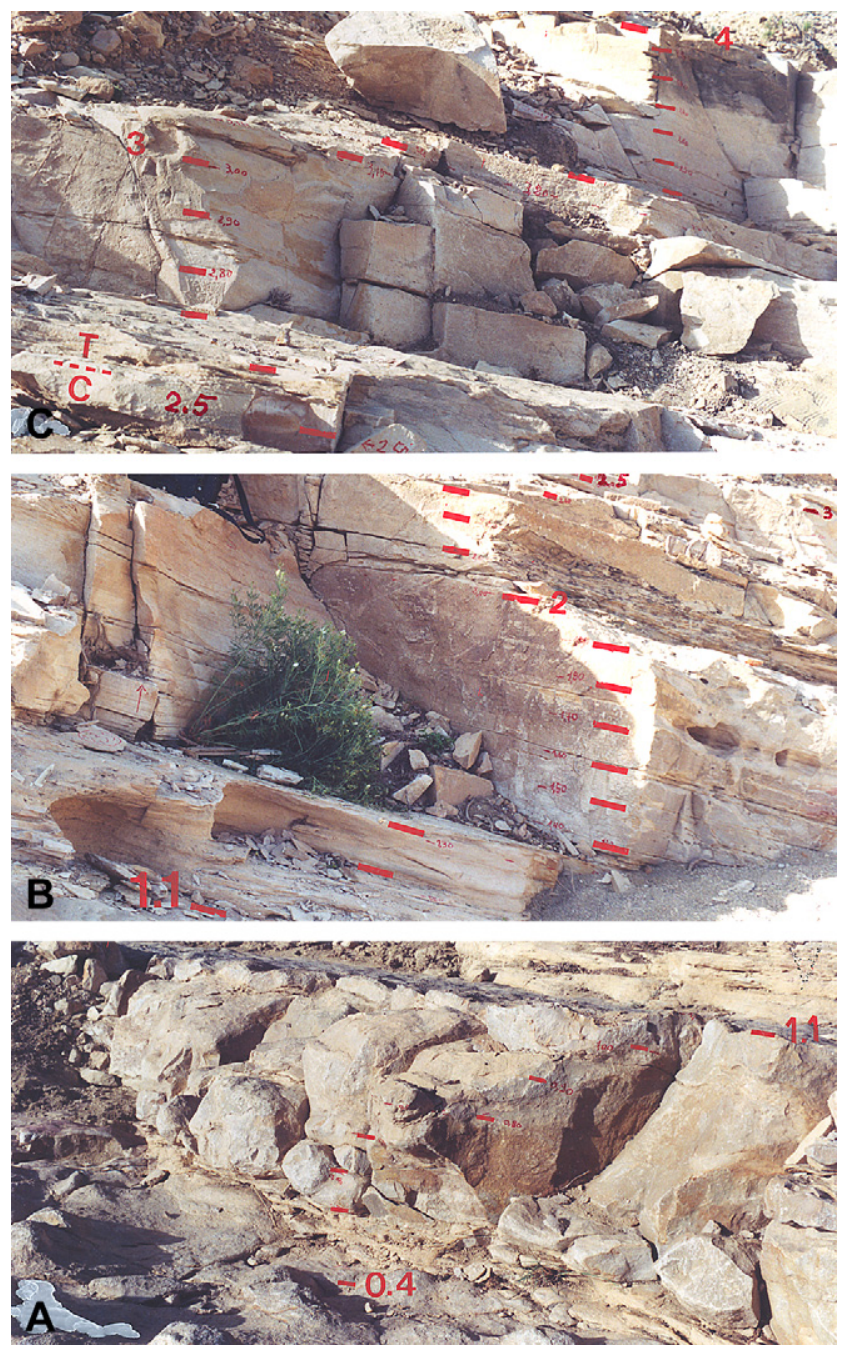

Fig. 10. Detailed aspects of the Bou Ghanem BGB section. A, Lower left: undulated surface of top LU 4 (= BGB 0.40); middle: undulated and lenticular calcispheric limestones of LU 5; 1.1: undulated top of LU 5; upper right: laminated limestones of LU 6-7 of the Bahloul s.s. B, Lower left: top of LU $5=$ BGB 1.1; 1.1 to 2.70: LU 6, 7 and 8 of the Bahloul s.s.: laminated black limestones, altered white surfaces. C, Between BGB 2.50 and 2.60: Cenomanian-Turonian boundary; BGB 2.70: top of LU 8; BGB 3.40: top of LU 9 which is the top of the Bahloul s.s. Photographs by F. Robaszynski.

and textures are gathered together in Fig. 14 and will be discussed on below.

\subsection{Ammonites}

The uppermost Fahdene Formation, the greatest part of the pre-Bahloul unit, does not give ammonites. In the BGB section, it is only the lenticular and hummocky limestone beds of the uppermost pre-Bahloul (LU 5) which provide several ammonites such as Calycoceras sp., Nigericeras sp., Pseudaspidoceras sp. and a vascoceratid. Above, into the LU 8, the FO and LO of P. pseudonodosoides define bio-events 3 and 4 and the biozone of the same name, which is the last of the Cenomanian (and is equivalent to the Neocardioceras juddii Zone of the Boreal realm, as discussed in Amédro et al., 2005). About $10 \mathrm{~cm}$ above the last P. pseudonodosoides in a correlative bed of the BGC section, appear the first specimens of Watinoceras sp., an ammonite indicative of the basal Turonian (bio-event 7). Just above, this taxon is accompanied by Fagesia sp. and higher up, at BGB 4.10 , by 

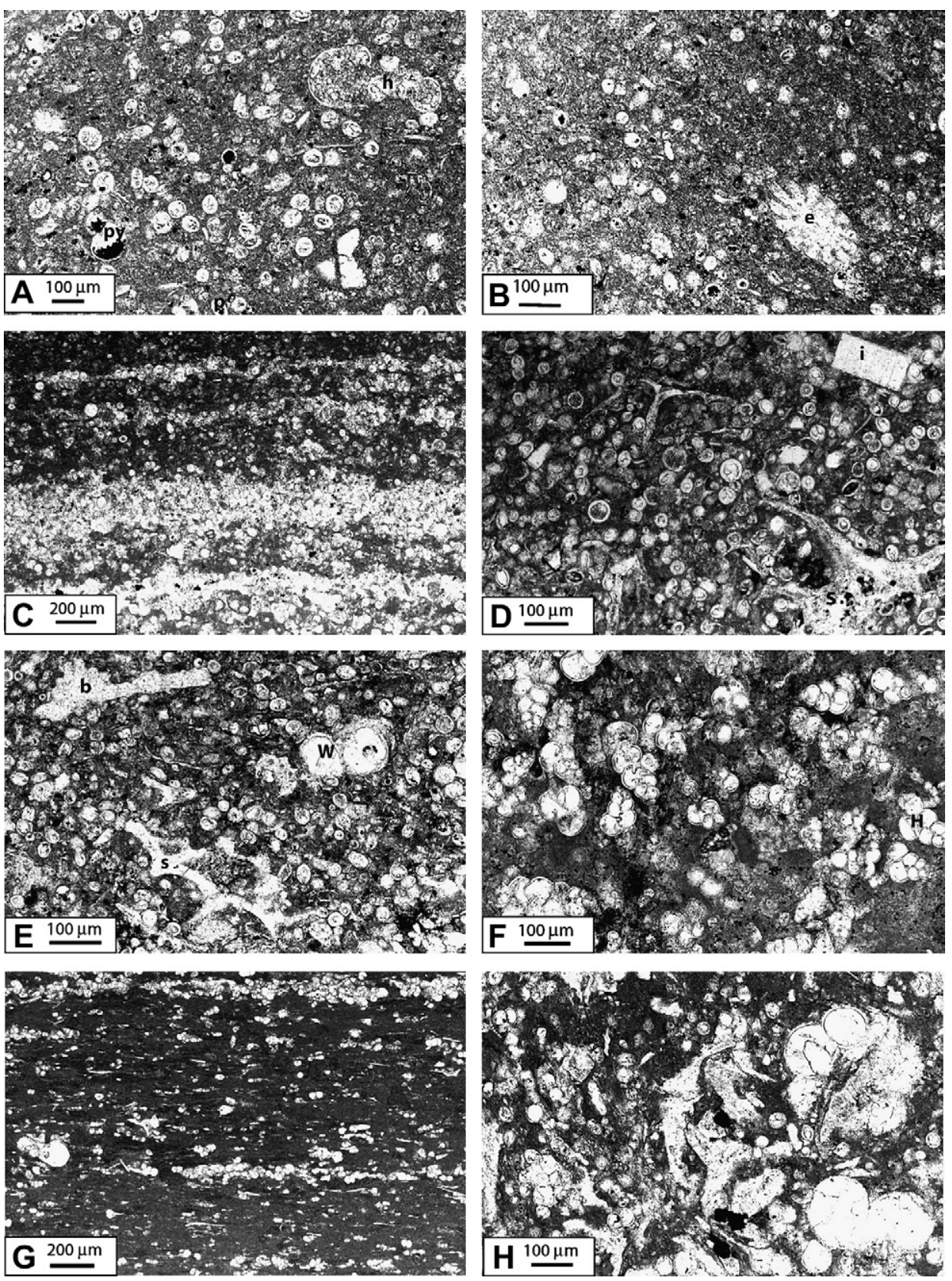

Fig. 11. Bou Ghanem section: microfacies of the uppermost Fahdene Fm. and of the Bahloul Fm. pro parte. LU = lithological unit. Photographs by M. Caron. A, LU 1: BGA 1.50, $\times 55$, marly limestone of the Fahdene Fm. Wackestone with calcispheres, pithonellids (p), hedbergellid (h), sometimes pyritized (py). B, LU 2: BGA 2.95, $\times 70$, limestone burrow infilling: wackestone with calcispheres sometimes pyritized, echinoid spine (e). C, LU 3: BGD 0.70, $\times 35$, first laminated black limestone of the Bahloul Fm. (pre- Bahloul succession): lines of calcispheres, pithonellids, and some heterohelicids in limestone with organic matter. D, LU 4: BGE 3.00, $\times 70$, massive white limestone (bar of the pre-Bahloul): numerous calcispheres, pithonellids, saccocomids (s), and inoceramid fragments (i) in a wackestone to packstone texture. E, LU 5: BGB 0.45, $\times 90$, lenticular limestone (higher part of the preBahloul): calcispheres, pithonellids, bioclastes (b), saccocomid (s), rare planktic foraminifera (w: probably a Whiteinella). F, LU 6: BGB 1.15, $\times 80$, first level of the Bahloul sensu stricto: Heterohelix bio-event at the base of the platy limestones. Monogeneric accumulation of Heterohelix (H) opportunistic planktic foraminifera regarded as bio-event 3. G, LU 7: BGA $1.60, \times 35$, black laminated limestone of the Bahloul s.s.: three laminae of planktic foraminifera (mainly heterohelicids, rare whiteinellids) and rare "filaments" in a limestone containing black organic matter. H, LU 7: BGB $2.00, \times 70$, top of the LU 7, very bioclastic, with saccocomids, echinoids, and microfossil fragments.

Thomasites sp. and especially by $P$. flexuosum, a marker species of another ammonite zone (bio-event 8 ).

\subsection{Cenomanian-Turonian boundary}

The 2nd Symposium on the Cretaceous Stage Boundaries held in Brussels 1995 (Bengtson, 1996) recommended placing the lower boundary of the Turonian stage at the base of the Watinoceras devonense Zone, that is to say above the Neocardioceras juddii Zone of the latest Cenomanian corresponding to the Pseudaspidoceras pseudonodosoides Zone of the Tethyan realm (Amédro et al., 2005). So, the base of the Turonian stage at Bou Ghanem is above BLB 2.50 (last P. pseudonodosoides) and at, or slightly below BLB 2.60 (first Watinoceras sp. in the correlative BGC 0.40).

\subsection{Planktic foraminifera}

All the foraminifera were examined in thin sections. The rotaliporids give two bio-events of international value (LO of R. cushmani and LO of Th. multiloculata). The last R. cushmani was found near 

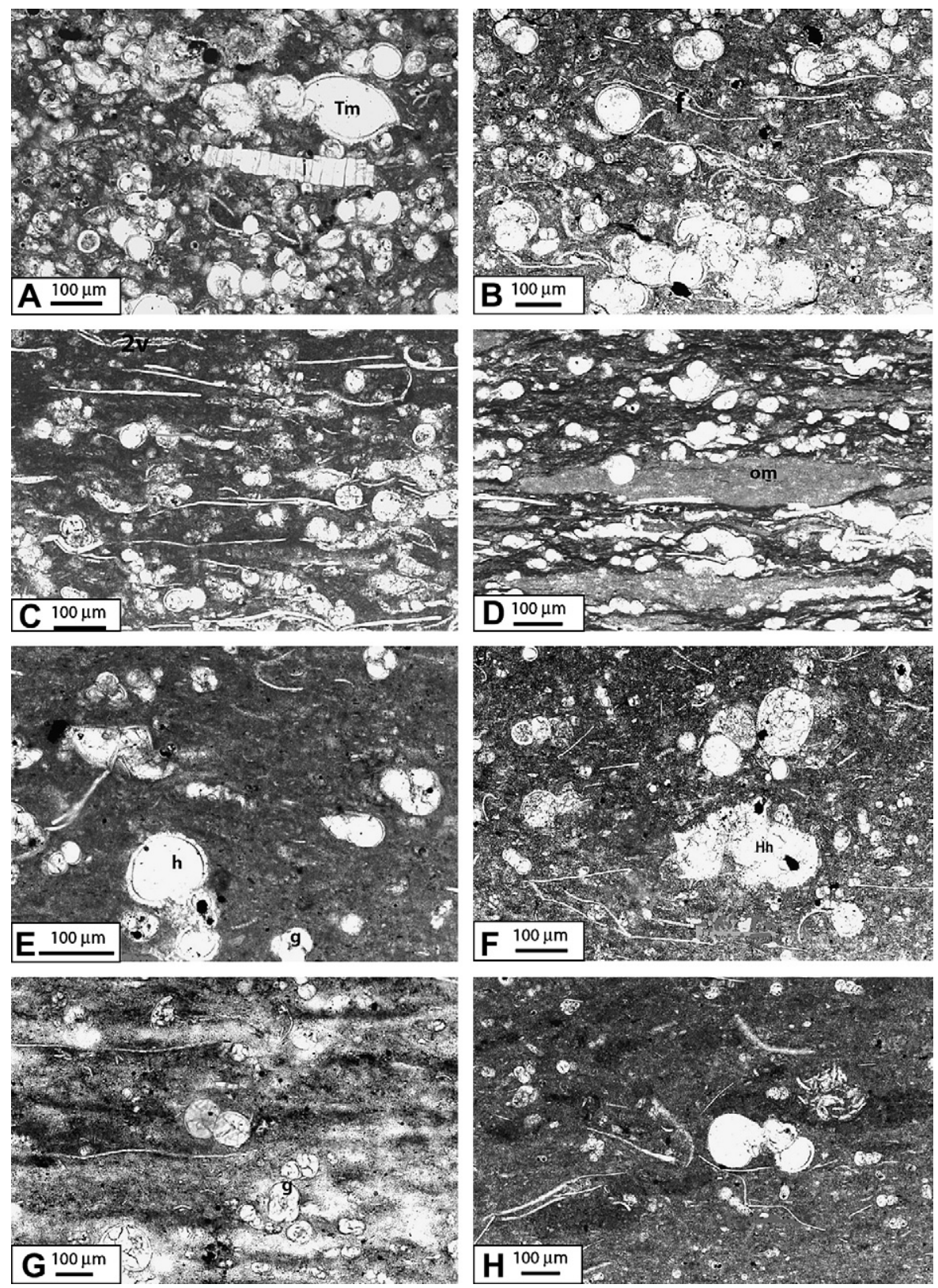

Fig. 12. Bou Ghanem section: microfacies of the upper Bahloul Fm. showing the "Bositra-like filaments" and microfacies of the Annaba Member (Kef Fm. pars). Photographs by M. Caron. A, LU 8: BGB 2.50, $\times 90$, lenticular limestone in the Bahloul s.s.: in a wackestone to packstone texture, calcispheres, inoceramid fragment (i), heterohelicids, guembelitriids, whiteinellid. A good section of Thalmanninella multiloculata (Tm = "Anaticinella auct.") is representative of the last occurrence of this rotaliporid. It is bio-event 5. B, LU 8: BGB 2.55, $\times 80$, black platy limestone: calcispheres, whiteinellids, and first development of "filaments" (f) representing bio-event 6 just before the entry of the basal Turonian ammonite Watinoceras at about BGB 2.60 = BGC 0.40). C, LU 9: BGB 2.70, $\times 90$, black laminated limestone: the "filaments" bio-event in a matrix of limestone and organic matter, associated with small planktic foraminifera. Rarely these micro-bivalves show their two valves (2v). D, LU 9: BGB 2.75, $\times 85$, black limestone with calcispheres, planktic foraminifera, and lenticular peloids of organic matter (om) in a wackestone texture. E, LU 10: BGB 3.60, $\times 130$, base of the Annaba Member: grey massive limestone with hedbergellid (h), rare "filaments," and numerous guembelitriids (g) in a mudstone texture. F, LU 11: BGC $2.35, \times 90$, dark grey platy limestones: wackestone with whiteinellid fragments, heterohelicids, "filaments," and a section of a planktic foraminifera close to the species Helvetoglobotruncana helvetica but a rather high-spired form, slightly atypical (Hh, possible bio-event 9), in a wackestone texture. G, LU 11: BGC 2.75, $\times 65$, top of the platy limestone: hedbergellid, "filaments," and several guembelitrids (g) in a mudstone texture. H, LU 12: BGC 5.00, $\times 65$, marly limestone of the Annaba Member: Whiteinella, heterohelicids, some calcispheres, and filaments, in a mudstone texture.

the middle of the thick white calcispheric limestones of the LU 4 (BGE $1.90 \mathrm{~m}$, Fig. 13A). As this morphotype is rare in thin sections showing essentially calcispheres, it may be possible its vertical distribution extends higher up the LU 4. Anyhow the LO of R. cushmani lies somewhere in the LU 4 and that constitutes bio-event 1. The second bio-event given by a rotaliporid species concerns the LO of Th. multiloculata, a species at the end of the evolutionary line of the genus Thalmanninella, one of the three genera of the polyphyletic rotaliporid group (González Donoso et al., 2007). To our knowledge, this species is restricted to the uppermost part of the Cenomanian Stage. Its last presence was noted at the level BGB $2.50 \mathrm{~m}$ (Fig. 13H) and is bio-event 5 (superposed to bio-event 4 or LO $P$. pseudonodosoides).

Whiteinellids with globular chambers are present to abundant in practically all the samples (they are known as "Grandes Globigérines" of literature, the term being created by Sigal, 1955, for 

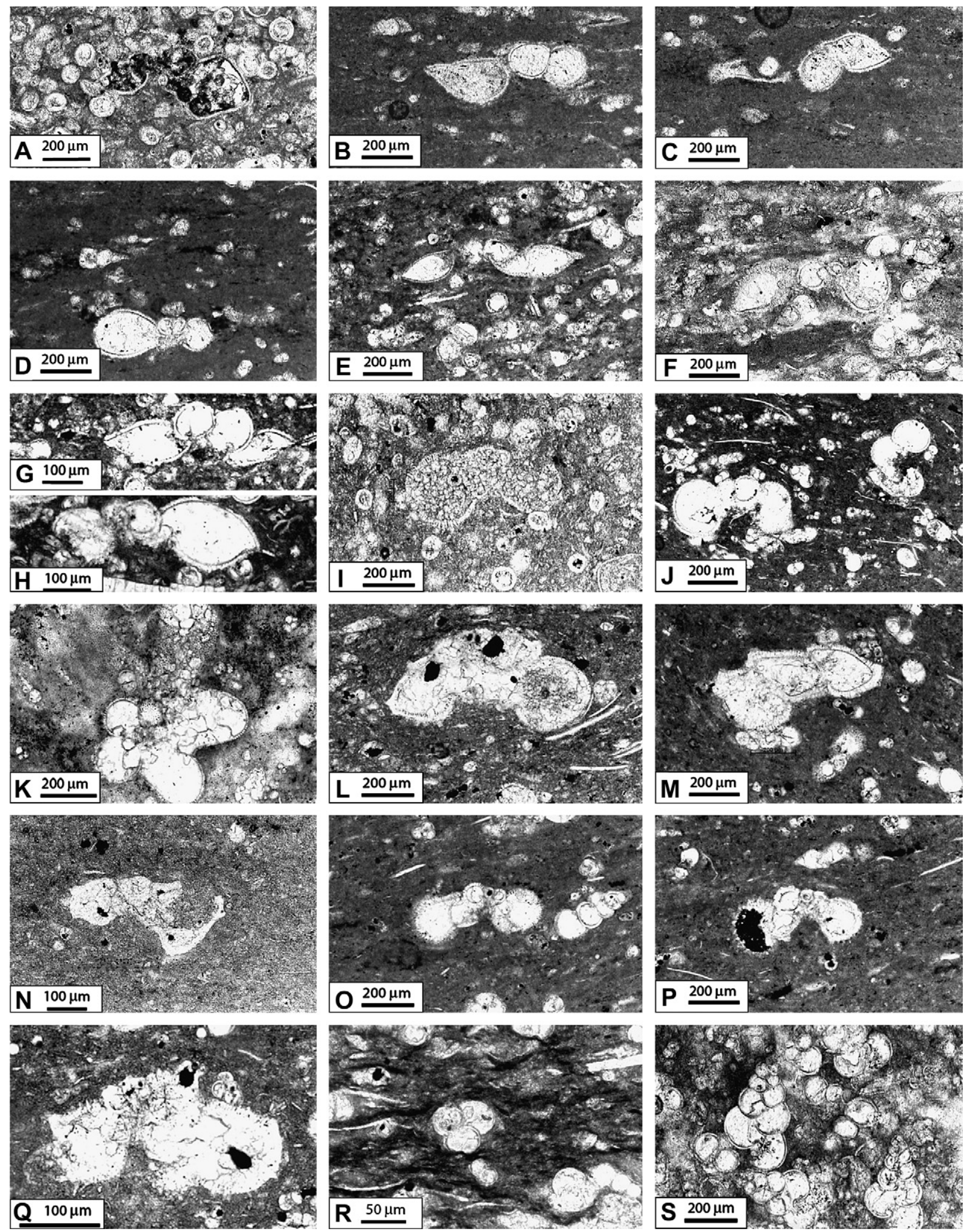

Fig. 13. Bou Ghanem section: microfossils and marker bio-events. Photographs by M. Caron. A, Rotalipora cushmani (Morrow), BGE 1.90, in LU 4 (pre-Bahloul), the last occurrence of the species is bio-event 1. B, C, D, Thalmanninella multiloculata (Morrow), BGB 1.60, in LU 7 (Bahloul s.s.), it is the "Anaticinella" of Caron et al. (2006). E, F, Th. multiloculata, BGB 2.10, at the base of LU 8 (Bahloul s.s.). G, Th. multiloculata, BGD 0.90, LU 3 (base of pre-Bahloul). H, Th. multiloculata, BGB 2.50, LU 8 upper part (Bahloul s.s.). At the level 2.50 is the last occurrence of this species representing the end of the Thalmanninella lineage, which is bio-event 4. I, Whiteinella sp. probably W. archaeocretacea Pessagno, BGA 1.50, in LU 1 (Fahdene Fm.). J, Whiteinella sp., BGB 3.10, in LU 9 (Bahloul s.s.). K, Clavihedbergella sp., BGC 2.75, in LU 11 (Annaba Mb.). L, Praeglobotruncana stephani (Gandolfi), BGB 4.10, in LU 10 (base of the Annaba Mb.). M, Dicarinella hagni/imbricata, BGB 3.60, in LU 10 (base of Annaba Mb.). N, Dicarinella hagni (Scheibnerova), BGC 5.80, in LU 12 (marly part of the Annaba Mb). O, P, Whiteinella praehelvetica (Trujillo), P shows a very early form of the species, with a slight flattening of the chambers on the spiral side; BGB 3.60, in LU 10 (base of the Annaba Mb.). Q Helvetoglobotruncana helvetica (Bolli): the specimen is also a rather highspired form; BGC 2.35, in Lu 12 (near the base of the Annaba Mb.). The first occurrence of the species is bio-event 9. R, Guembelitria sp., BGB 2.80, at the base of LU 9 (in the upper part of the Bahloul s.s.) S, Heterohelix spp., BGB 1.15, base of LU 6 which corresponds to the base of the Bahloul s.s. This level, where Heterohelix are accumulated is bio-event 3. 
a north-african biozone encompassing the Cenomanian-Turonian boundary. The "grandes Globigérines" gather some hedbergellids as $H$. delrioensis and especially all whiteinellids as $W$. brittonensis, baltica, paradubia, aprica, archaeocretacea, praehelvetica). The species $W$. praehelvetica was found several times in the Turonian part of the section but already in the uppermost part of the Cenomanian. This observation confirms those made in the Upper Cenomanian of two distant sections: wadi Bahloul in central Tunisia and Pueblo in the United States of America (Caron et al., 2006). The FO of the species is a good bio-event but it probably lies below the base of the Bou Ghanem section as presented here.

As the specimen found at BGC $2.35 \mathrm{~m}$ is the marker species $H$. helvetica (Fig. 13) we would have good evidence for placing bioevent 9 with this FO of the species.

The sudden development of heterohelicids (or "Heterohelix shift" of Leckie, 1985, Leckie et al., 1998, Meyers et al., 2001 and Caron et al., 2006) with probably $H$. globulosa and H. moremanibut the two species are difficult to distinguish in thin sectionsgives a good regional and sometimes global marker. As named by Huber et al. (1999) this "Heterohelix-dominated assemblage" is bio-event 2 .

\section{4. "Filaments"}

The "filaments," as they appear in thin sections, were small bivalves which planktic phase of their larvas developed in nutrientrich seas. As they became adult they sank and lived in a moderate oxygenated environment. But, in oxygen-deficient waters where the Bahloul laminated facies were deposited, they died in great number. That explains the accumulation of these died out juvenile bivalves forming bio-event 6 which seems to be global and placed at BGB $2.55 \mathrm{~m}$. The position of the bio-event 6 is just above the last uppermost Cenomanian ammonite Pseudaspidoceras pseudonodosoides (at BGB $2.50 \mathrm{~m}$ ) and just below the first Lower Turonian Watinoceras sp. (BGC $0.40=$ BGB 2.60).

\subsection{Bio-events}

In short, the succession of bio-events at Bou Ghanem is as follows from top to bottom:
9. FO $H$. helvetica
8. FO P. flexuosum
7. FO Watinoceras sp.
6. "filaments" bio-event
5. LO Th. multiloculata
4. LO P. pseudonodosoides
3. FO P. pseudonodosoides
2. Heterohelix bio-event
1. LO R. cushmani

\section{Comparisons and discussion}

\subsection{Comparison with other sections in central Tunisia}

As a succession of 9 bio-events is now demonstrated in and around the condensed Bahloul Formation of Bou Ghanem, it becomes possible to compare it with sections where the same bioevents have been recognized. Four sections with the CenomanianTuronian transition in the Bahloul Formation have previously been studied: at wadi Bahloul (BLB), at Koudiat el Azreg (ZR), at wadi Smara near Kalaat Senan (SM) and West Tajerouine (TJ). The description of the lithological successions and of the fossil content of these sections were presented in several papers: Robaszynski et al. (1990, 1993), Accarie et al. (1996), Caron et al. (1999, 2006), Amédro et al. (2005).

Table 2 gives the exact position of each bio-event of the 5 sites with, in addition, the place of the geochemical peaks of $\delta^{13} \mathrm{C}$ relative to the four previously studied sections.

All the data of Table 2 are transferred onto the lithological log in Fig. 15 which suggests some remarks.

i. In a general way, most of the event-lines appear to be parallel and, even though it is strongly condensed, the Bou Ghanem section can be correlated with a good level of confidence with other sections of central Tunisia.

ii. What appears immediately is that the succession of most of the 9 bio- and 5 geochemical events is coherent in all the sections except in some details expressed hereafter.

iii. The lines of LO Th. multiloculata and LO P. pseudonodosoides cross the other parallel lines several times. But, as they are two last occurrences it is understandable that it is generally more difficult to find evidences of the extinction of a taxon.

iv. It is the same case for the LO R. cushmani which is above the $\delta^{13} \mathrm{C}$ peak I at BLB and ZR and below the peak I at SM and TJ.

\subsection{Comparison with distant areas}

A tentative correlation was tried with two sections belonging to the Boreal realm: the Eastbourne site in England (Paul et al., 1999; Keller et al., 2001), and the Pueblo site in USA (Cobban and Scott, 1972; Caron et al., 2006) the latter being the Global boundary Stratotype, Section and Point (GSSP) of the base of the Turonian stage. The $\delta^{13} \mathrm{C}$ geochemical events are very good markers for correlation but, in addition, several bio-events are common between sections occurring in three distant continents such as: FO Metoicoceras geslinianum, LO R. cushmani, LO Th. multiloculata, "filaments" bio-event and FO of Watinoceras, FO of $P$. flexuosum and FO of $H$. helvetica. On the other hand, several bio-events such as the sudden development of Heterohelix, the FO and LO of P. pseudonodosoides appear to be of a more regional value as they are particular to the Tethyan realm. In other respects, the Heterohelix bio-event is especially located in laminated black limestones and, moreover, lamination is caused by the accumulation of great number of Heterohelix spp. forming surfaces of weakness allowing an easy cleavage of this kind of limestone.

\section{Chronological geo-history of the Bou Ghanem site and its surroundings at the Cenomanian-Turonian transition}

The study of bio- and geochemical events at five sites, comprising the Bou Ghanem condensed section, allows us to propose a chronological scenario for the sedimentary history of, at least, a great part of central Tunisia.

\subsection{Fahdene Formation ( $L U 1$ and 2)}

The top of the Fahdene Formation was deposited in an open sea environment with a calcisphere supply generated in shallow waters from a southern platform and with ammonites such as Calycoceras and Eucalycoceras spp. Planktic foraminifera develop complex morphotypes of K-speciation, single- and double-keeled forms such as rotaliporids ( $R$. cushmani, Th. greenhornensis), praeglobotruncanas (P. stephani), dicarinellids ( $D$. algeriana, hagni, imbricata), marginotruncanas ( $M$. marianosi) and some globular morphotypes as hedbergellids and whiteinellids (W. brittonensis, archaeocretacea, praehelvetica). 


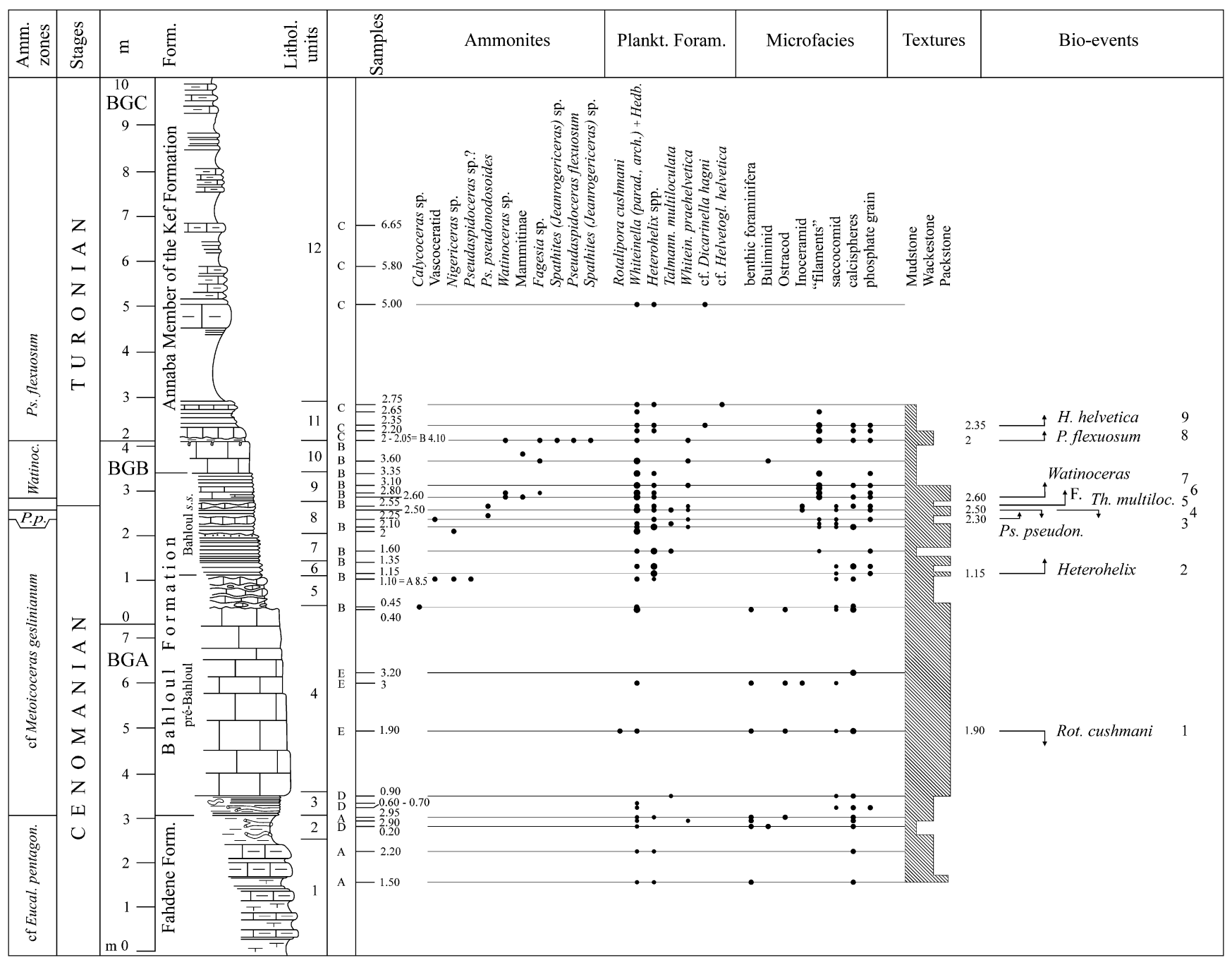

Fig. 14. Analytic data for the composite Bou Ghanem section: macro- and microfossil content, microfacies and bio-events. P.p.: Pseudaspîdoceras pseudonodosoides.

\subsection{Pre-Bahloul unit (LU 3, 4 and 5)}

This unit starts with an oxygen depletion in the sea bottom leading to the deposition of dark grey to black platy limestones (LU 3 ) that mark the beginning of the Cenomanian-Turonian turnover (Caron et al., 2006) which implies several bio-events, successively:

- inadaptation of the planktic foraminiferal complex morphotypes: decrease of single and double-keeled forms with extinction of $R$. cushmani (bio-event 1, BGE 1.90) in the thick calcispheric limestone of LU 4;

- development of less evolved planktic foraminiferal species of short and shallow life-cycle (r-speciation) giving the Heterohelix bio-event (bio-event 2, BGB 1.15);

- reduction of the frequency of large ammonites of the Calycoceras group and first occurrence of new smaller taxa such as Metoicoceras geslinianum (ZR section, Amédro et al., 2005) and P. pseudonodosoides (bio-event 3, BGB 2.30).

\subsection{Bahloul sensu stricto ( $L U$ 6, 7, 8 and 9)}

The oxygen depletion increased tense in the bottom sea waters and was marked by the deposition of organic matter as pelletoids in black laminated limestones. The laminae correspond to a great accumulation of heterohelicids which are primitive morphotypes of r-speciation living within surface water as opportunists with a very high productivity. Correlatively, complex planktic foraminifera living deeper in the water column diminish and, for

Table 2

Position of bio- and geochemical-events (I, * to IV) in 5 sites in central Tunisia

\begin{tabular}{llllllc}
\hline & & BLB & ZR & SM & TJ & BG \\
\hline 9 & H. helvetica & 34.85 & - & - & 14 & C 2.35 \\
& IV & 34.25 & 83.20 & 140.50 & - & - \\
8 & Ps. flexuosum & - & 82.60 & 137 & - & C 2 \\
7 & Watino./Fagesia & 27.60 & 78 & 128.2 & 14 & B 2.60 \\
6 & "Filaments" & 26.50 & 77.50 & 127.75 & 13.90 & B 2.55 \\
5 & Th. multiloculata & 27.20 & 76.50 & 124.90 & 13.50 & B 2.50 \\
4 & Ps. pseudonod & 27 & 75 & - & - & B 2.50 \\
& III & 24.50 & 74.50 & 126.80 & 12.80 & - \\
& II & 12 & 68 & 121.50 & 8.30 & - \\
3 & Ps. pseudonod & 10 & 67.6 & 120.80 & - & B 2.30 \\
& $*$ & 7.75 & 63 & 119.25 & 5 & - \\
2 & Heterohelix & 6.20 & 59.35 & 118.50 & 4.05 & B 1.15 \\
& I & 5.5 & 59.35 & 117.40 & 3.50 & - \\
1 & Rot. cushmani & 5.25 & 57.50 & 114.80 & 1 & E 1.90 \\
& Wh. praehelv & 5.00 & - & - & - & - \\
\hline
\end{tabular}

Left: numbers 1 to 9 refer to bio-events 1 to 9 . The numbers below each section index refer to the measurements in metres. BLB: wadi Bahloul, ZR: Koudiat el Azreg, SM: wadi Smara, TJ: Tajerouine, BG: Bou Ghanem. All localities are situated in Fig. 1. 


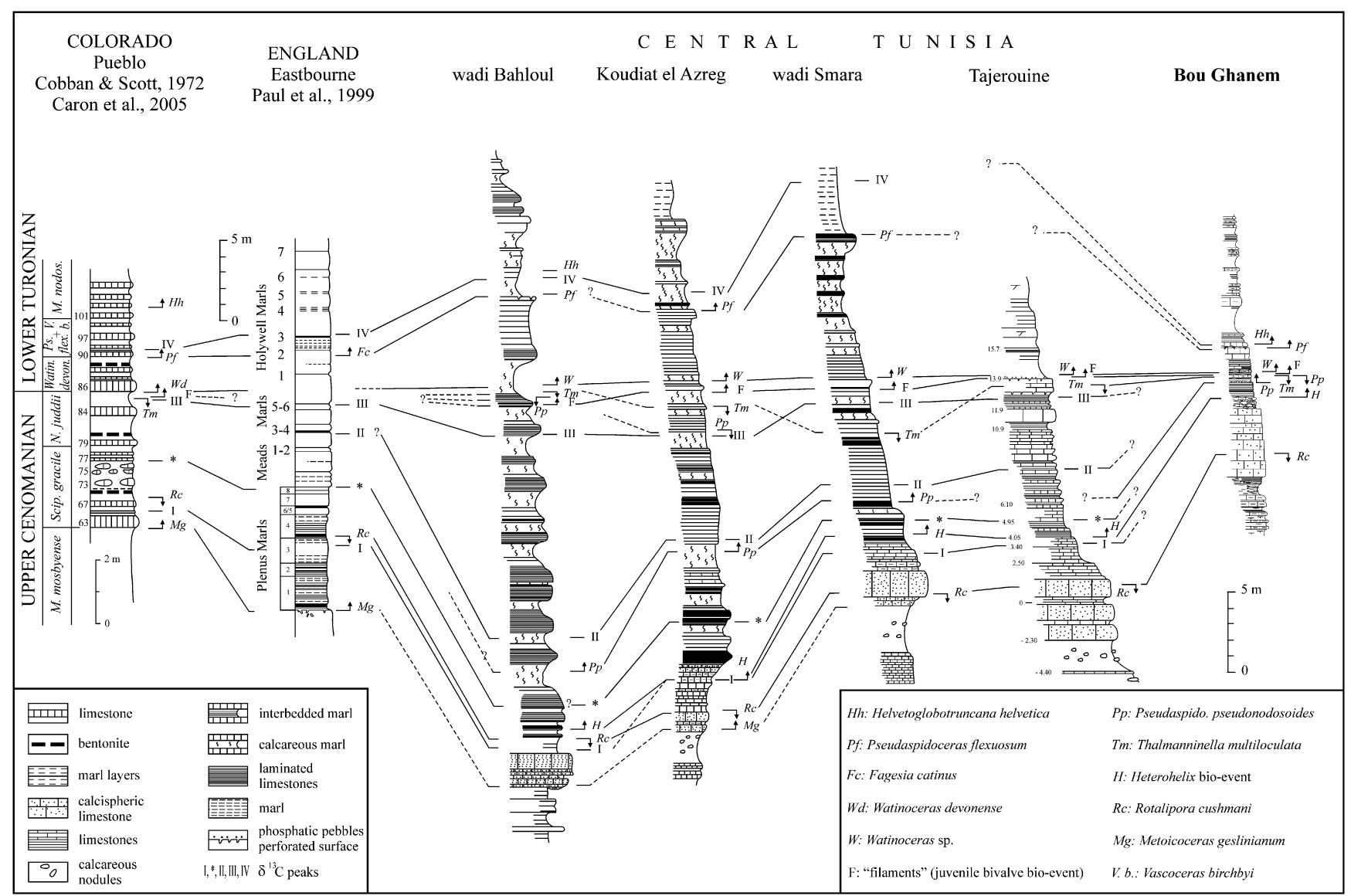

Fig. 15. Bio-event and geochemical $\left(\delta^{13} \mathrm{C}\right)$ correlation of the Bou Ghanem site with other sites in central Tunisia and with sites in England and Colorado.

example, the keeled Thalmanninella progressively lose their keel to give Th. multiloculata ('Anaticinella' auct.) chambers of which became pinched to globular (Gonzalez Donoso et al., 2007). Finally, in such hypoxic environments the ammonite P. pseudonodosoides becomes extinct (bio-event 4, BGB 2.50) coeval with or followed by the extinction of Th. multiloculata (bio-event 5 , BGB 2.50).

When anoxic conditions become very strong, limestones are completely black but remain laminated by the permanent deposition of heterohelicids produced in great number in the surface waters.

In addition, juvenile bivalve died out accumulation is registered as white "filaments" (as they appear under the microscope in a black background of organic matter). That corresponds to larvaplanktic bivalves which cannot attain their adult phase because of the oxygen-deficient waters, and die in great number. This is bioevent 6 (BGB 2.5) seeming to be global, and it is immediately followed by the emergence of the new ammonoid taxon Watinoceras (bio-event 7, BGC $0.40=$ BGB 2.60) which marks the base of the Turonian Stage and is coeval with the appearance of the genus Fagesia.

\subsection{Annaba Member (LU 11 and 12)}

More oxygen in the sea-water column, linked to the transgressive pulse of the Lower Turonian, leads to the restoration of biodiversity with a re-development of calcispheres and complex morphotypes of planktic foraminifera such as Dicarinella spp. and the appearance of new taxa of ammonites such as P. flexuosum (bioevent 8 , BGC $2=$ BGB 4.10) and of new planktic complex morphotypes such as Marginotruncana sp. and $H$. helvetica (bioevent 9, BGC 2.35).

Then, the transgressive pulse develops into the Lower Turonian with the deposition of grey (oxygenated environments) marls and limestones forming the Annaba Member of the Kef Formation.

\section{Conclusions}

The Bou Ghanem site exposes a $2.4 \mathrm{~m}$ condensed section of black laminated limestones belonging to the Bahloul sensu stricto when elsewhere in central Tunisia its thickness is generally between 15 to $30 \mathrm{~m}$. The detailed study of macro- and microfossil bio-events in this reduced Bahloul facies shows the existence of all bio-events found in the dilated successions of wadi Bahloul, Koudiat el Azreg and wadi Smara.

A high resolution stratigraphy was derived with ammonites and microfossils and defined the following succession of bio-events: 1. LO Rotalipora cushmani, 2. Heterohelix bio-event, 3. FO Pseudaspidoceras pseudonodosoides, 4. LO P. pseudonodosoides, 5. LO Thalmanninella multiloculata, 6. "filaments" bio-event, 7. FO Watinoceras/Fagesia spp, 8. FO Pseudaspidoceras flexuosum, 9. FO Helvetoglobotruncana helvetica.

The turnover at the Cenomanian-Turonian transition as defined by Caron et al. (2006) is fully confirmed.

It is more than likely the five $\delta^{13} \mathrm{C}$ geochemical peaks could be registered in the Bou Ghanem section, a complementary sampling at their probable place suggested by the position of the bio-events would be a further step to a more complete knowledge of the succession. 
The comparison with other sections in central Tunisia and in other continents (Eastbourne and Pueblo) leads to define common bio-events of strong value for long distance and intercontinental correlations, and especially: FO M. geslinianum, LO R. cushmani, LO Th. multiloculata, "filaments" bio-event, FO Watinoceras, FO P. flexuosum and FO $H$. helvetica (partly, as this last FO seems to be diachronous).

It is to be noted that, in the absence of recordings of Watinoceras ammonite which is rather rare-, a very good proxy, seemingly of global occurrence, is the accumulation of died out juvenile bivalve "filaments" which is registered everywhere in great number just before or coeval with the first Turonian marker ammonite Watinoceras.

\section{Acknowledgements}

The Faculté Polytechnique de Mons, the Faculté de Géologie de Bizerte and the Institut de Géologie de Fribourg supported this work and are thanked for their technical services. We are thankful to Dr Michel Hennebert (Faculté Polytechnique de Mons) for his remarks on the manuscript and for his help in the modification of several figures. We also express our gratitude to two anonymous reviewers for their critical comments which improved the manuscript.

\section{References}

Abdallah, H., 1995. Découverte du Membre Bahloul au-dessous du Membre Gattar dans la chaîne nord des Chotts (Centre-Sud de la Tunisie): conséquences de la transgression-anoxie du Cénomanien supérieur. Comptes rendus de l'Académie des Sciences, Paris 320 (II a), 463-468.

Abdallah, H., Sassi, S., Meister, C., Souissi, R., 2000. Stratigraphie séquentielle et paléogéographie à la limite Cénomanien-Turonien dans la région de GafsaChotts (Tunisie centrale). Cretaceous Research 21, 35-106.

Accarie, H., Emmanuel, L., Robaszynski, F., Baudin, F., Amédro, F., Caron, M., Deconinck, J.-F., 1996. La géochimie isotopique du carbone $\left(\delta^{13} \mathrm{C}\right)$ comme outil stratigraphique. Application à la limite Cénomanien-Turonien en Tunisie centrale. Comptes rendus de l'Académie des Sciences, Paris II a (322), 579-586.

Accarie, H., Robaszynski, F., Amédro, F., Caron, M., Zagrarni, M.F., 2000. Stratigraphie événementielle au passage Cénomanien-Turonien dans le secteur occidental de la plate-forme de la Tunisie centrale (formation Bahloul, région de Kalaat Senan). Annales des Mines et de la Géologie, Tunisie 40, 63-80.

Amédro, F., Accarie, H., Robaszynski, F., 2005. Position de la limite CénomanienTuronien dans la formation Bahloul de Tunisie centrale: apports intégrés des ammonites et des isotopes du carbone $\left(\delta^{13} \mathrm{C}\right)$. Eclogae Geologicae Helvetiae 98, 151-167.

Bengtson, P., 1996. The Turonian stage and substage boundaries. Bulletin de l'Institut royal des Sciences naturelles de Belgique, Sciences de la Terre 66 (Suppl.), 69-79.

Ben Haj Ali, N., Razgallah, S., Ben Haj Ali, M., Kennedy, W.J., 1994. La formation Bahloul dans sa localité type: précisions stratigraphiques basées sur les ammonites et les foraminifères planctoniques. Notes du service géologique de la Tunisie $60,35-58$.

Burollet, P.F., 1956. Contribution à l'étude stratigraphique de la Tunisie centrale. Annales des Mines et de la Géologie, Tunisie 18, 1-345.

Burollet, P.F., Dumestre, A., Keppel, D., Salvador, A., 1954. Unités stratigraphiques en Tunisie centrale. 19ème Congrès Géologique International d'Alger. 21, pp. 243-254.

Burollet, P.F., Robaszynski, F., 1992. Les événements de la limite Cénomanien-Turonien en Tunisie centrale: la Formation Bahloul. Géologie alpine 67, 3-42.

Caron, M., Robaszynski, F., Amédro, F., Baudin, F., Deconinck, J.-F., Hochuli, P., Von Salis-Perch Nielsen, K., Tribovillard, N., 1999. Estimation de la durée de l'événement anoxique global au passage Cénomanien-Turonien. Approche cyclostratigraphique dans la Formation Bahloul en Tunisie centrale. Bulletin de la Société géologique de France 170, 145-160.

Caron, M., Dall'Agnolo, S., Accarie, H., Barrera, E., Kauffman, E.G., Amédro, F., Robaszynski, F., 2006. High-resolution stratigraphy of the Cenomanian-Turonian boundary interval at Pueblo (USA) and wadi Bahloul (Tunisia): stable isotope and bio-events correlation. Geobios 39, 171-200.

Cobban, W.A., Scott, G.R., 1972. Stratigraphy and ammonite fauna of the Graneros Shale and Greenhorn limestone near Pueblo, Colorado. Professional Paper United States Geological Survey 645, 1-108.

Fournié, D., 1978. Nomenclature lithostratigraphique des séries du Crétacé supérieur au Tertiaire de Tunisie. Bulletin des Centres de Recherche ExplorationProduction Elf Aquitaine, Pau 2, 97-148.

González Donoso, J.-M., Linares, D., Robaszynski, F., 2007. The Rotaliporids, a polyphyletic group of Albian-Cenomanian planktonic foraminifera. Emendation of genera. Washington D.C. Journal of Foraminiferal Research 37, 175-186.

Huber, B.T., Bralower, T.J., Leckie, R.M., 1999. Paleoecological and geochemical signatures of Cretaceous anoxic events: a tribute to William V. Sliter. Journal of Foraminiferal Research 29, 313-506.

Keller, G., Han, Q., Adatte, T., Burns, S.J., 2001. Palaeoenvironment of the Cenomanian-Turonian transition at Eastbourne, England. Cretaceous Research 22, 391-422.

Layeb, M., Belayouni, H., 1992. La formation Bahloul au Centre et au Nord de la Tunisie. Un exemple de bonne roche mère de pétrole à fort potentiel pétrolier. Actes des 2èmes journées de géologie tunisienne appliquée à la recherche des hydrocarbures (Tunis, novembre 1989). Mémoires de l'ETAP 3, 489-503.

Leckie, R.M., 1985. Foraminifera of the Cenomanian-Turonian boundary interval, Greenhorn Formation, Rock Canyon Anticline, Pueblo Colorado. In: Pratt, L.M. Kauffman, E.G., Zelts, F.B. (Eds.), Fine-grained Deposits and Biofacies of the Cretaceous Western Interior Seaway: Evidence of Cyclic Sedimentary Processes. SEPM, 2nd Annual Meeting, Golden, CO, Field Trip Guide-book 4, pp. 139-149.

Leckie, R.M., Yuretrich, R.F., West, O.L.O., Finkelstein, D., Schmidt, M., 1998 Paleoceanography of the southern Western Interior Sea during time of the Cenomanian-Turonian boundary (Late Cretaceous). In: Dean, W., Arthur, M.A. (Eds.), Stratigraphy and Paleoenvironments of the Cretaceous Western Interior Seaway. SEPM Concepts in Sedimentology and Paleontology $6 \mathrm{pp}$. 101-126.

Maamouri, A.L., Zaghbib-Turki, D., Matmati, M.F., Chikhaoui, M., Salaj, J., 1994. La Formation Bahloul en Tunisie centro-septentrionale: variations latérales, nouvelle datation et nouvelle interprétation en terme de stratigraphie séquentielle. Journal of African Earth Sciences 18, 37-50.

Meyers, S.R., Sageman, B.B., Hinnov, L., 2001. Integrated quantitative stratigraphy of the Cenomanian-Turonian bridge creek limestone member using evolutive harmonic analysis and stratigraphic modeling. Journal of Sedimentary Research 71, 628-644.

Paul, C.R.C., Lamolda, M.R., Mitchell, S.F., Waziri, M.R., Gorostidi, A., Marshall, J.D., 1999. The Cenomanian-Turonian boundary at Eastbourne (Sussex, UK): a proposal European reference section. Palaeogeography, Palaeoclimatology, Palaeoecology 150, 83-121.

Robaszynski, F., 2005. The Cenomanian of the Kalaat Senan area and its lower and upper boundaries. Géologie alpine, Série Colloques et Excursions 5, 125-155.

Robaszynski, F., Caron, M., Dupuis, C., Amédro, F., González Donoso, J.-M., Linares, D., Hardenbol, J., Gartner, S., Calandra, F., Deloffre, R., 1990. A tentative integrated stratigraphy in the Turonian of central Tunisia: formations, zones, and sequential stratigraphy in the Kalaat Senan area. Bulletin des Centres de Recherches Exploration-Production Elf Aquitaine 14, 213-384.

Robaszynski, F., Hardenbol, J., Caron, M., Amédro, F., Dupuis, C., González Donoso, J.-M., Linares, D., Gartner, S., 1993. Sequence stratigraphy in a distal environment: the Cenomanian of the Kalaat Senan region (central Tunisia). Bulletin des Centres de Recherches Exploration-Production Elf Aquitaine 17, 395-433.

Robaszynski, F., Caron, M., Amédro, F., Dupuis, C., Hardenbol, J., González Donoso, J.-M., Linares, D., Gartner, S., 1994. Le Cénomanien de la région de Kalaat Senan (Tunisie centrale). Litho-biostratigraphie et interprétation séquentielle. Revue de Paléobiologie, Genève 12, 351-505.

Sigal, J., 1955. Notes micropaléontologiques nord-africaines. 1. Du Cénomanien au Santonien: zones et limites en faciès pélagique. Compte rendu sommaire des séances de la Société Géologique de France 8, séance du 8 mai 1955. pp. $157-160$.

Wignall, P.B., 1994. Black Shales. Geology and Geophysics Monographs, vol. 30. Oxford University Press, pp. 1-130. 